OPEN ACCESS

Edited by:

Maximilian Michel,

University of Michigan, USA

Reviewed by:

Helene Volkoff,

Memorial University, Canada Lisette Maddison,

Vanderbilt University, USA

${ }^{*}$ Correspondence: José L. Soengas jsoengas@uvigo.es

Specialty section:

This article was submitted to Neuroendocrine Science,

a section of the journal

Frontiers in Neuroscience

Received: 29 November 2016 Accepted: 19 December 2016

Published: 05 January 2017

Citation:

Conde-Sieira M and Soengas JL (2017) Nutrient Sensing Systems in

Fish: Impact on Food Intake Regulation and Energy Homeostasis.

Front. Neurosci. 10:603.

doi: 10.3389/fnins.2016.00603

\section{Nutrient Sensing Systems in Fish: Impact on Food Intake Regulation and Energy Homeostasis}

\author{
Marta Conde-Sieira and José L. Soengas * \\ Laboratorio de Fisioloxía Animal, Departamento de Bioloxía Funcional e Ciencias da Saúde, Facultade de Bioloxía, \\ Universidade de Vigo, Vigo, Spain
}

Evidence obtained in recent years in a few species, especially rainbow trout, supports the presence in fish of nutrient sensing mechanisms. Glucosensing capacity is present in central (hypothalamus and hindbrain) and peripheral [liver, Brockmann bodies (BB, main accumulation of pancreatic endocrine cells in several fish species), and intestine] locations whereas fatty acid sensors seem to be present in hypothalamus, liver and BB. Glucose and fatty acid sensing capacities relate to food intake regulation and metabolism in fish. Hypothalamus is as a signaling integratory center in a way that detection of increased levels of nutrients result in food intake inhibition through changes in the expression of anorexigenic and orexigenic neuropeptides. Moreover, central nutrient sensing modulates functions in the periphery since they elicit changes in hepatic metabolism as well as in hormone secretion to counter-regulate changes in nutrient levels detected in the CNS. At peripheral level, the direct nutrient detection in liver has a crucial role in homeostatic control of glucose and fatty acid whereas in BB and intestine nutrient sensing is probably involved in regulation of hormone secretion from endocrine cells.

Keywords: nutrient sensors, fish, hypothalamus, liver, Brockmann bodies, intestine, food intake, homeostasis

\section{NUTRIENT SENSING MECHANISMS IN FISH}

Since sensing and responding to fluctuations in environmental nutrient levels is a requisite for life, is not surprising that different organisms are able to detect extracellular and intracellular levels of sugars, amino acids, and lipids. The sensing of a specific nutrient may occur directly through binding of the sensed molecule to the sensor, or indirectly through detection of a related molecule that reflect nutrient abundance (Ogunnowo-Bada et al., 2014; Efeyan et al., 2015). We provide in the next sections a summary of the findings obtained in fish about glucose and fatty acid sensors.

As for the other main nutrient, amino acid, the increase in mammals in the levels of specific branched-chain amino acids (BCAA) such as leucine inhibits food intake. This process occurs through activation of amino acid sensing systems mediated by activation of target of rapamycin (mTOR) and/or inhibition of AMP-activated protein kinase (AMPK) signaling, or via activation of BCAA metabolism (Heeley and Blouet, 2016; Morrison et al., 2016). Furthermore, the deficiency in essential amino acids (including BCAA) elicits an increase in food intake through amino acid sensing systems mediated by general control nondepressable 2 and eukaryotic initiation factor $2 \alpha$ (Fromentin et al., 2012; Maurin et al., 2014). In fish, no studies have attempted yet to evaluate the possible presence and functioning of comparable amino acid sensing mechanisms and their relationship with food intake control. Their presence in central areas regulating food intake is 
however reasonable considering that most fish are carnivorous, and therefore they are strongly dependent (certainly much more than omnivorous mammals in which most studies have been carried out to date) on dietary protein/amino acid levels for functioning. The only studies available in fish demonstrated in peripheral tissues like muscle and liver the effect of changes in amino acid levels in mRNA abundance of mTOR (Seiliez et al., 2008; Wacyk et al., 2012; Tu et al., 2015; Liang et al., 2016; Xu et al., 2016).

The hypothetical mechanisms involved in sensing of glucose, fatty acid, and amino acid in fish are summarized in Figure 1.

\section{Glucosensors}

Glucosensing is the ability of specialized cells to detect changes in the levels of glucose. This ability relates to food intake control and counter-regulatory responses to changes in levels of plasma metabolites in brain areas like hypothalamus and hindbrain. In pancreatic endocrine cells and intestine it relates to hormone release whereas in liver relates to the metabolic switch between glucose utilization and production in liver. There are several glucosensing mechanisms characterized in mammals. The best known is that mediated by glucokinase (GK), as demonstrated in brain neurons, pancreatic $\beta$-cells and hepatocytes (Blouet and Schwartz, 2010; Ogunnowo-Bada et al., 2014; Efeyan et al., 2015). In this mechanism (Marty et al., 2007; Polakof et al., 2011d), glucose is taken up by glucose facilitative carrier type 2 (GLUT2), phosphorylated to glucose 6-phosphate by GK, and then metabolized through glycolysis increasing intracellular ATP/ADP ratio (Figure 1). The increased ratio induces closure of ATP-dependent inward rectified potassium channel $\left(\mathrm{K}_{\text {ATP }}^{+}\right)$inducing the depolarization of membrane and the entry of calcium into the cell through L-type voltagedependent calcium channel. This entry of calcium finally results in changes in neuronal activity (brain), modulation of hormone release (endocrine cells) or changes in metabolism (liver). There is also evidence in mammals for GK-independent glucosensing mechanisms as also displayed in Figure 1 (Fioramonti et al., 2004; Marty et al., 2007; González et al., 2009; Thorens, 2012; Donovan and Watts, 2014). The expression of liver X receptor (LXR) (Mitro et al., 2007) responds to increased glucose levels eliciting a decrease in gluconeogenic capacity (Anthonisen et al., 2010; Archer et al., 2014). The sweet taste receptors (formed by

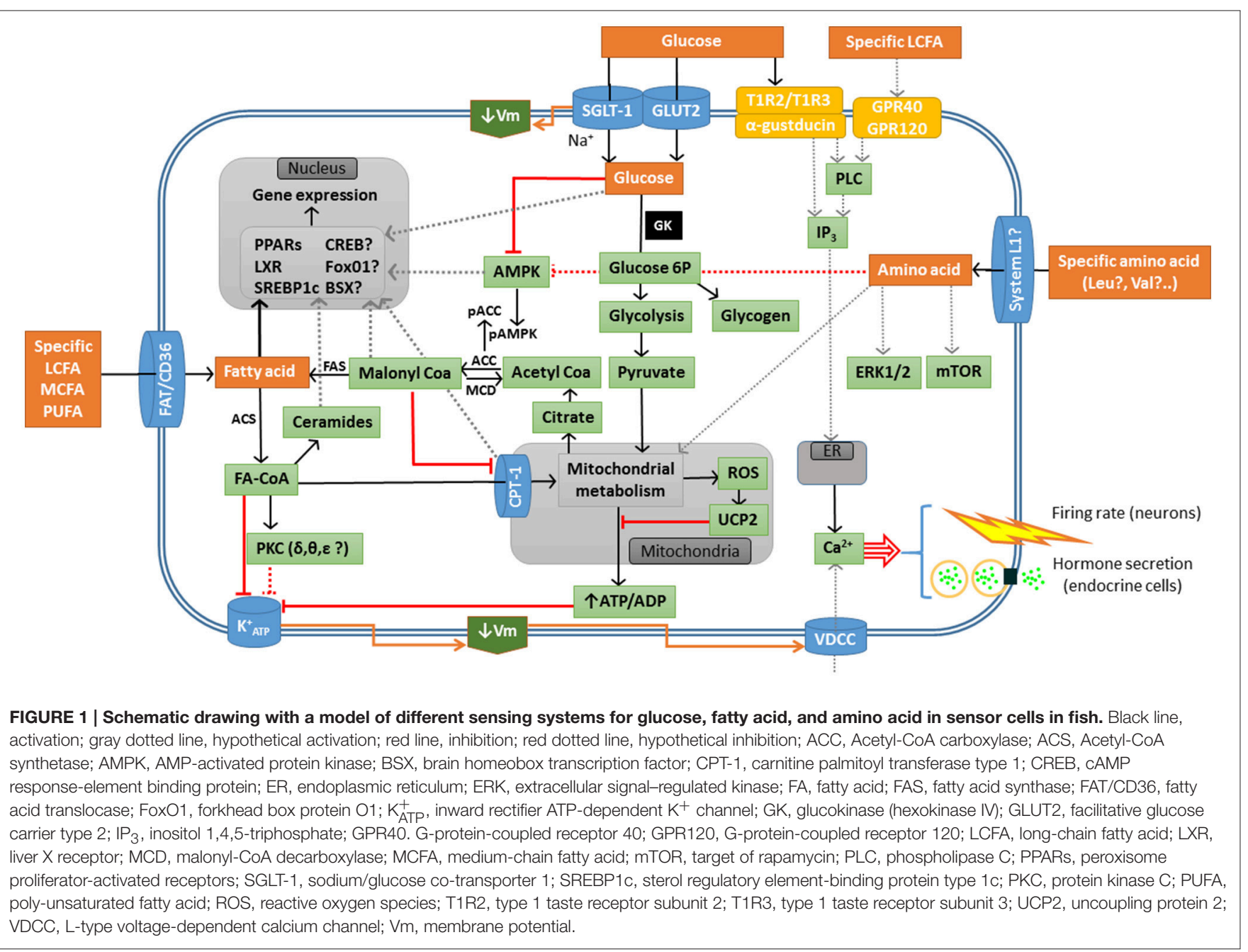


type 1 taste receptor subunits (T1Rs) 2 and 3 , and $\alpha$-gustducin) respond to changes in glucose levels activating an intracellular signaling cascade (Ren et al., 2009; Kyriazis et al., 2014; Murovets et al., 2015; Herrera Moro Chao et al., 2016). Enhanced glucose levels induce increased expression of sodium/glucose cotransporter 1 (SGLT-1) (Díez-Sampedro et al., 2003; González et al., 2009; Thorens, 2012). The mitochondrial production of reactive oxygen species (ROS) leads to increased expression of uncoupling protein 2 (UCP2) in response to increased glucose levels (Beall et al., 2010; Diano and Horvath, 2012). These different systems might relate since, for instance, T1R3 and $\alpha$-gustducin are necessary for SGLT-1 response to increased carbohydrate levels in the diet (Wauson et al., 2013).

In fish, evidence obtained in recent years support the presence of a GK-dependent glucosensing mechanism in central and peripheral areas of rainbow trout (Polakof et al., 2011d; Soengas, 2014). Indeed, in rainbow trout changes in the levels of glucose induced dietary (Polakof et al., 2008b,c), intraperitoneal (IP) (Polakof et al., 2007a, 2008a; Conde-Sieira et al., 2010a,b, 2012b; Otero-Rodiño et al., 2015), in vitro (Polakof et al., 2007b; Aguilar et al., 2011; Conde-Sieira et al., 2011, 2012a), or intracerebroventricular (ICV) (Polakof and Soengas, 2008) treatments resulted in changes in glucosensing mechanisms in hypothalamus and hindbrain. These include changes in GK mRNA abundance and activity, glucose and glycogen levels, GLUT2 mRNA abundance, glycolytic and glycogenic potentials, and in the activity of $\mathrm{K}_{\mathrm{ATP}}^{+}$. Besides the studies carried out in rainbow trout, a recent study provided evidence of glucose sensing properties in several hypothalamic nuclei in medaka (Hasebe et al., 2016). In peripheral tissues of rainbow trout, the presence and functioning of GK-dependent glucosensing mechanisms is supported by findings in liver (Soengas et al., 2006; Conde-Sieira et al., 2012b), Brockmann bodies (BB, main accumulation of endocrine pancreatic cells) (Polakof et al., 2007a,b, 2008b,c), and intestine (Polakof et al., 2010a; Polakof and Soengas, 2013). Interestingly, the response of glucosensing systems to glucose is more important during the day than during the night in liver but not in hypothalamus, hindbrain, and $\mathrm{BB}$ whose responses to hyperglycemic treatment were similar at night and day (CondeSieira et al., 2012a).

The presence of GK-independent glucosensing mechanisms and their response to changes in glucose levels has recently been assessed in different central and peripheral areas of rainbow trout (Polakof and Soengas, 2013; Otero-Rodiño et al., 2015, 2016a,b,c). These include hypothalamus (mitochondrial activity, sweet taste receptor, and LXR), hindbrain (SGLT-1), liver (sweet taste receptor), $\mathrm{BB}$ (sweet taste receptor, LXR, and mitochondrial activity), and intestine (sweet taste receptor, SGLT-1, and LXR). Furthermore, a recent study (Balasubramanian et al., 2016) also demonstrated increased mRNA abundance of T1R2 and LXR in brain of rainbow trout nutritionally programmed to cope with enhanced carbohydrate levels in the diet.

Figure 2 summarizes the integrative responses of glucosensing systems in different fish tissues to an increase or decrease in glucose levels.

\section{Fatty Acid Sensors}

In mammals fatty acid sensing systems are involved in hypothalamus and hindbrain in the detection of changes in the levels of long-chain fatty acid (LCFA) thus contributing to energy homeostasis control (Migrenne et al., 2007; Gao et al., 2013; Duca and Yue, 2014; Efeyan et al., 2015). The best known mechanism is of metabolic nature (Figure 1) in a way that a rise in LCFA levels results in increased levels of malonylCoA, which inhibits carnitine palmitoyl transferase-1 (CPT1) then resulting in the inability of mitochondria to import fatty acid-CoA for oxidation (López et al., 2005, 2007). There is also evidence for the presence of alternative mechanisms in mammals (Figure 1). These include the increased binding capacity of fatty acid translocase (FAT/CD36) in response to elevated LCFA levels resulting in changes in the expression of several transcription factors (Le Foll et al., 2009). The activation of specific isoforms of protein kinase $\mathrm{C}$ in response to increase levels of LCFA results in the inhibition of $\mathrm{K}_{\text {ATP }}^{+}$activity (Benoit et al., 2009; Blouet and Schwartz, 2010). The activity of $\mathrm{K}_{\text {ATP }}^{+}$ inhibited by increased capacity of mitochondria to produce ROS in response to increased LCFA levels (Blouet and Schwartz, 2010). Finally, the activity of lipoprotein lipase increases in response to enhanced availability of triglycerides resulting in increased levels of LCFA stimulating G-protein-coupled receptors 40 and 120 (Picard et al., 2013; Ekberg et al., 2016). These systems apparently respond to specific LCFA, such as the monounsaturated fatty acid oleate (C18:1 n-9) (López et al., 2007; Blouet and Schwartz, 2010; Duca and Yue, 2014). The ability of other classes of LCFA differing in the length of their acyl chain and/or in their degree of unsaturation to elicit the activation of these systems has been scarcely assessed to date. The available studies in mammals indicate that neither saturated fatty acids like palmitate (C16:0) nor the presence of two (such as in linoleate, C18:2n-6) or three (such as in docosahexanoate, C22:6 n-3) double bonds activate fatty acid sensing systems (Gomez-Pinilla and Ying, 2010; Ross et al., 2010; Schwinkendorf et al., 2011; Greco et al., 2014).

Lipids are major nutrients in fish where they metabolically support many different processes (Sheridan, 1994; Tocher, 2003; Polakof et al., 2010b). Therefore, not surprisingly, many studies evaluated the effects of different dietary lipids in fish metabolism (Morash et al., 2009; Torstensen et al., 2009; Sánchez-Gurmaches et al., 2010; Figueiredo-Silva et al., 2012a,b,c; Martinez-Rubio et al., 2013). However, only recent studies provide evidence for the presence of fatty acid sensing systems in central areas of rainbow trout (Librán-Pérez et al., 2012, 2013a, 2014a,b, 2015a,b) and Senegalese sole (Conde-Sieira et al., 2015a) as well as in peripheral areas of rainbow trout (Librán-Pérez et al., 2012, 2013a,b,c, 2015c).

The treatment of rainbow trout with oleate induced responses compatible with fatty acid sensing in hypothalamus (LibránPérez et al., 2012, 2013a, 2014a), BB (Librán-Pérez et al., 2012, 2013a, 2015c), and liver (Librán-Pérez et al., 2013b,c, 2015c). These responses include decreased lipogenic and fatty acid oxidation capacities, reduced activity of $\mathrm{K}_{\mathrm{ATP}}^{+}$, and changes in the expression of transcription factors resultant of FAT/CD36 modulation. This response is comparable in general with that 


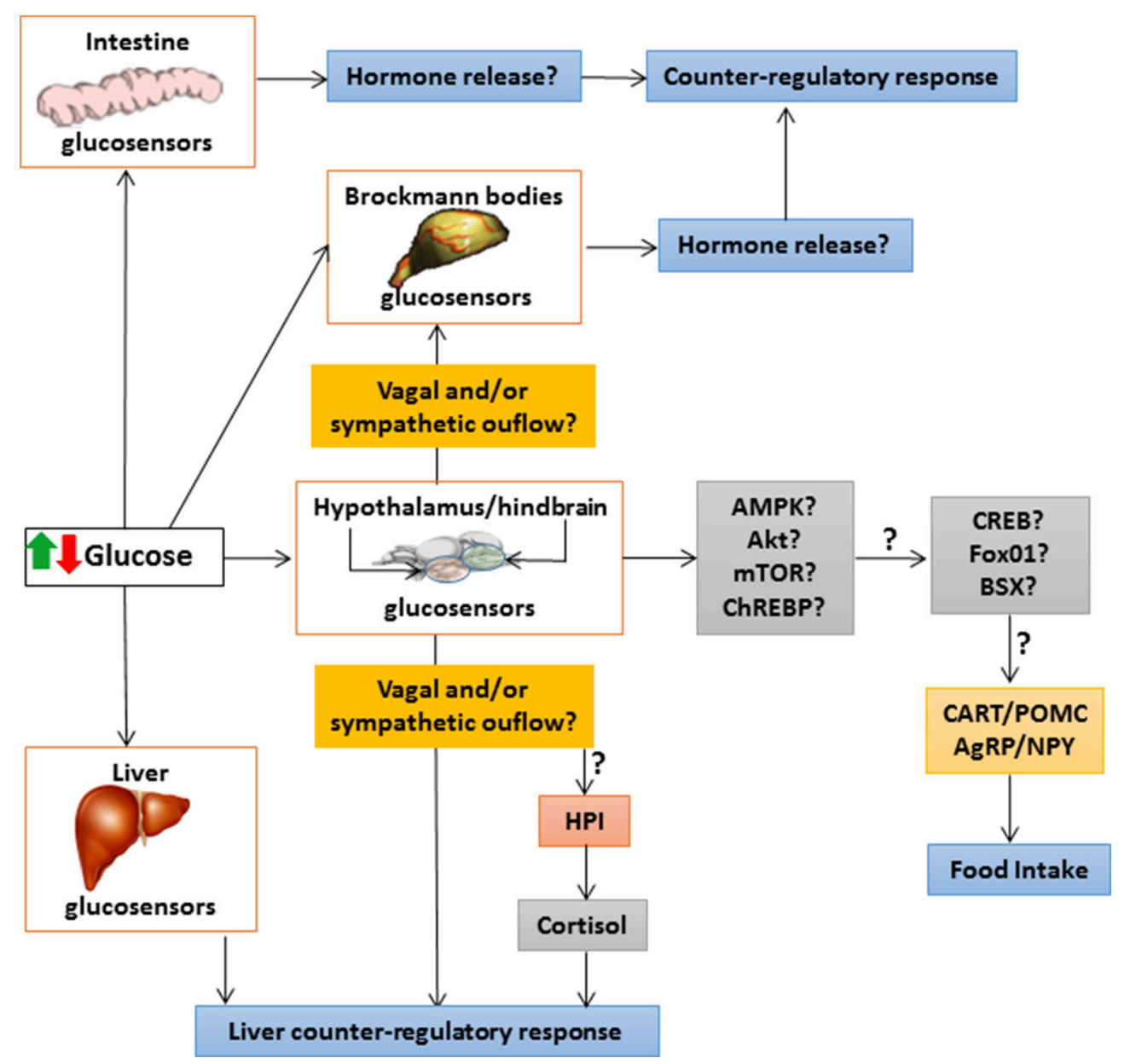

FIGURE 2 | Schematic drawing with a hypothetical model of integrative responses to an increase or decrease in glucose levels of glucosensing systems in different fish tissues. $\uparrow$, increase; $\downarrow$, decrease; ?, unknown; AgRP, agouti-related peptide; Akt, protein kinase B; AMPK, AMP-activated protein kinase; BSX, hypothalamic homeobox transcription factor; CART, cocaine- and amphetamine-related transcript; ChREBP, carbohydrate-responsive element-binding protein; CREB, CAMP response-element binding protein; FoxO1, forkhead box protein O1; HPI, hypothalamus-pituitary-interrenal axis; mTOR, target of rapamycin; NPY, neuropeptide Y; POMC, pro-opio melanocortin.

reported in mammals. Furthermore, in rainbow trout, similar responses occurred after treatment with the medium-chain fatty acid (MCFA) octanoate, and this is in contrast to mammals (Hu et al., 2011). This different behavior between fish and mammals might relate to the findings that body lipids in teleosts contain considerable amounts of MCFA (Davis et al., 1999; Trushenski, 2009) and/or MCFA oxidation in fish, at least in rainbow trout, is equally preferred compared with that of LCFA (Figueiredo-Silva et al., 2012a), in contrast with mammals (Ooyama et al., 2009). The response of fatty acid sensing systems in rainbow trout hypothalamus to increased levels of oleate or octanoate is also supported by the response of these tissues to specific inhibitors in vitro (Librán-Pérez et al., 2013a). Another peculiarity of fatty acid sensing systems in fish is their apparent capacity to respond to changes in the levels of polyunsaturated fatty acid (PUFA) of the n- 6 and particularly n-3 series. These PUFA are very relevant for fish since their diets are particularly rich in long chain PUFA (Sargent et al., 2002) and PUFA are therefore abundant in their tissues (Mourente and Tocher, 1992; Tocher, 2003). Furthermore, the brain of marine fish is particularly rich in n-3 PUFA, mainly in $\alpha$-linolenate (C18:3 n-3), eicosapentanoate (C20:5 n-3), and docosahexanoate (C22:6 n-3) (Tocher et al., 1992; Betancor et al., 2014). Conde-Sieira et al. (2015a) demonstrated that not only oleate but also $\alpha$-linolenate activated fatty acid sensing systems present in the hypothalamus of Senegalese sole. This is completely different to that described in mammals (see above) and may relate to the importance of n3 PUFA in fish. However, the capacity of PUFA to activate fatty acid sensing systems appears to be specific of certain PUFA since eicosapentanoate did not induce any significant change in fatty acid sensing systems (Conde-Sieira et al., 2015a).

Although levels of a particular fatty acid cannot be decreased, lipolysis inhibitors have been used to decrease circulating levels of all fatty acids, and this resulted in decreased activity of fatty 
acid sensing systems in mammals (Oh et al., 2012, 2014). A similar experimental approach in rainbow trout also resulted in the inhibition of fatty acid sensing systems in hypothalamus, BB, and liver, and these changes apparently relate to the activation of hypothalamus-pituitary-interrenal (HPI) axis (Librán-Pérez et al., 2014b, 2015d).

Figure 3 summarizes the integrative responses to changes in levels of specific fatty acids of fatty acid sensing systems in different fish tissues.

In summary, the evidence obtained in recent years support the presence in fish central and peripheral areas of several of the sensing mechanisms for glucose and fatty acid already characterized in mammalian models. However, these mechanisms are not exactly the same since besides responding to glucose or LCFA they also respond to other molecules such as MCFA or PUFA. Clearly, the assessment of amino acid sensing mechanism is lacking in fish, and this is of crucial importance considering that most fish species are carnivorous. Finally, there is also no information available regarding cellular mechanisms integrating information of main nutrient sensing systems into shared regulatory pathways.

\section{IMPACT OF NUTRIENT SENSING ON FOOD INTAKE REGULATION}

In mammals nutrient detection activates directly or indirectly hypothalamic neurocircuits involved in the regulation of food intake, energy expenditure, and homeostasis (Berthoud, 2002;
Morton et al., 2006, 2014; Berthoud and Morrison, 2008; Blouet and Schwartz, 2010). These circuits include two clearly defined populations of neurons mostly present in several hypothalamic nuclei including arcuate, as well as in other brain regions like hindbrain (Schwartz et al., 2000; Mobbs et al., 2005; Blouet and Schwartz, 2010; Efeyan et al., 2015). The first population responds to rises in circulating levels of glucose, fatty acid, or amino acid with the enhancement of AgRP and NPY expression. The second population responds to rises in levels of the same nutrients with enhanced co-expression of CART and POMC. Accordingly, in response to a rise in the levels of nutrients CART/POMC neurons depolarize while AgRP/NPY neurons hyperpolarize (Levin et al., 2004; Fioramonti et al., 2007). These populations also inhibit each other producing signals to higher-order neurons (Marty et al., 2007). Hypothalamic projections terminating in the hindbrain also causes a flow of efferent information to tissues involved in energy balance including liver, adipose tissue, and endocrine pancreas (Zheng and Berthoud, 2008).

In fish, NPY/AgRP and POMC/CART neurons are present in brain areas analogous to those in mammals (Cerdá-Reverter and Canosa, 2009). In addition, the expression of these neuropeptides relates to food intake control since feeding conditions change mRNA abundance of neuropeptides (Volkoff et al., 2005, 2009; Volkoff, 2006; Hoskins and Volkoff, 2012). Indeed, food deprivation decreased mRNA abundance of CART in goldfish (Volkoff and Peter, 2001), cod (Kehoe and Volkoff, 2007), and Atlantic salmon (Murashita et al., 2009) while values increased with re-feeding in channel catfish (Kobayashi et al., 2008), and
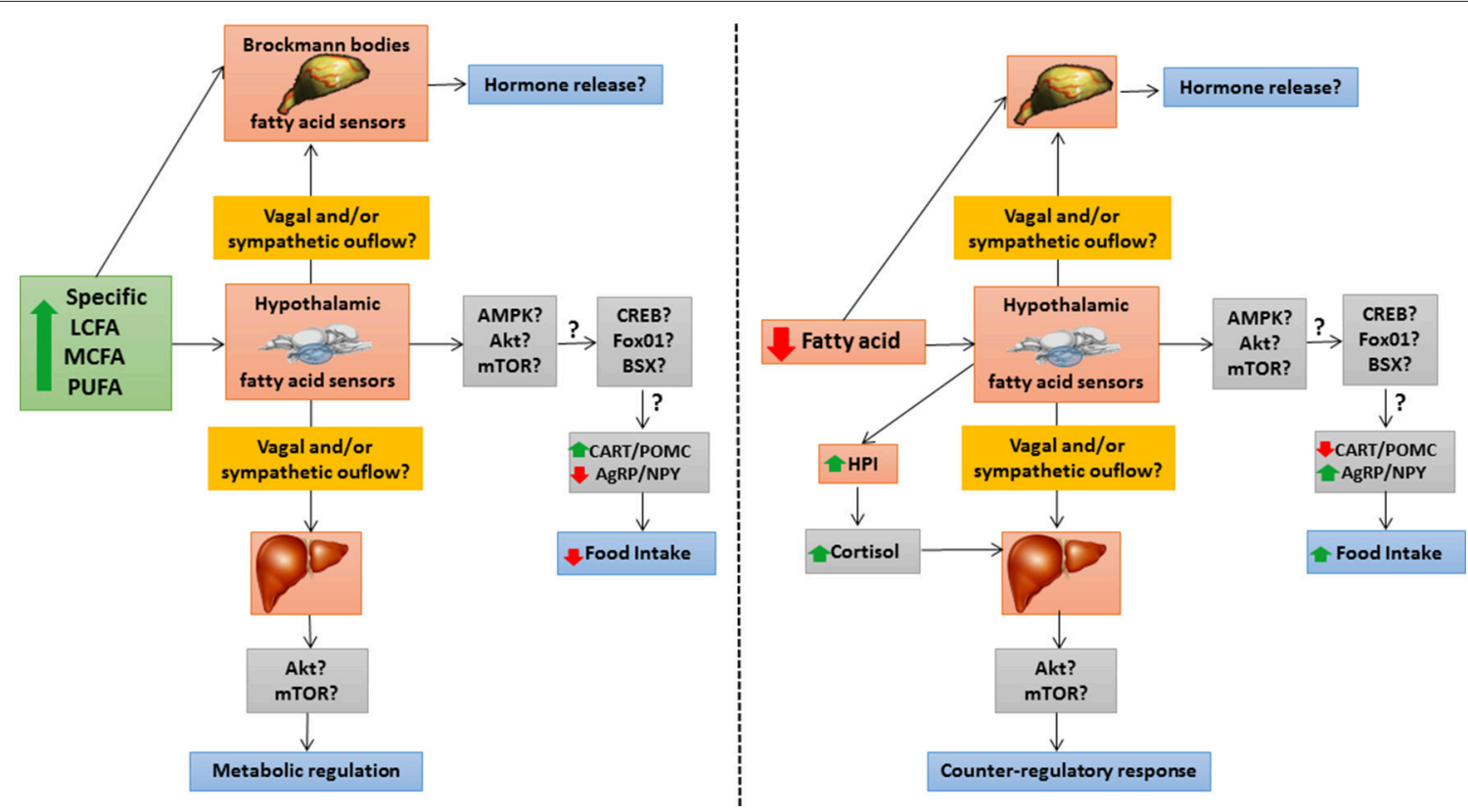

FIGURE 3 | Schematic drawing with a hypothetical model of integrative responses to an increase (left panel) or decrease (right panel) in levels of specific fatty acids of fatty acid sensing systems in different fish tissues. $\uparrow$, increase; $\downarrow$, decrease; ?, unknown; AgRP, agouti-related peptide; Akt, protein kinase B; AMPK, AMP-activated protein kinase; BSX, hypothalamic homeobox transcription factor; CART, cocaine- and amphetamine-related transcript; CREB, cAMP response-element binding protein; FoxO1, forkhead box protein O1; HPI, hypothalamus-pituitary-interrenal axis; LCFA, long-chain fatty acid; MCFA, medium-chain fatty acid; mTOR, target of rapamycin; NPY, neuropeptide Y; POMC, pro-opio melanocortin; PUFA, poly-unsaturated fatty acid. 
post-prandial changes occurred in goldfish (Volkoff and Peter, 2001) and channel catfish (Peterson et al., 2012). As for POMC, its mRNA abundance increased post-prandially in rainbow trout (Gong and Björnsson, 2014), medaka (Chisada et al., 2014), and Atlantic halibut (Gomes et al., 2015). The mRNA levels of AgRP increased with food deprivation in hypothalamus of goldfish (Cerdá-Reverter and Peter, 2003), zebrafish (Song et al., 2003), carp (Zhong et al., 2013), and sea bass (Agulleiro et al., 2013), though not in Atlantic salmon (Murashita et al., 2009) whereas no post-feeding changes occurred in medaka (Chisada et al., 2014). AgRP mRNA levels also increased in hypothalamus of GH-transgenic carp that also displayed increased food intake (Zhong et al., 2013). The mRNA abundance of NPY decreased post-feeding in grass carp (Zhou et al., 2013), goldfish (Kehoe and Volkoff, 2007), and zebrafish (Tian et al., 2015) but responses were contradictory in orange-spotted grouper (Tang et al., 2013), rainbow trout (Gong and Björnsson, 2014), and zebrafish (Chen et al., 2016). Finally, decreased mRNA abundance of NPY occurred in food-deprived rainbow trout (Gong et al., 2016b).

\section{Glucosensors and Regulation of Food Intake}

In mammals, the detection of changes in glucose levels by glucosensing mechanisms results in regulatory responses, including food intake, allowing the animal to control blood glucose levels (Marty et al., 2007). Accordingly, reduced glycaemia increases food intake whereas enhanced glycaemia decreases food intake (Morton et al., 2014; Ogunnowo-Bada et al., 2014; Rogers et al., 2016).

Similar changes in food intake in response to altered glucose levels occur in fish (Polakof et al., 2011d, 2012a). Decreased food intake occurred in rainbow trout fed with a diet enriched in carbohydrates (Kaushik et al., 1989; Suárez et al., 2002; Krogdahl et al., 2004; Polakof et al., 2008b,c; Figueiredo-Silva et al., 2013). A similar response was observed after ICV or IP hyperglycaemic treatments in the same species (Ruibal et al., 2002; Polakof et al., 2007a, 2008a; Conde-Sieira et al., 2010a,b, 2012b). In contrast, increased food intake occurred in rainbow trout fed a diet with a reduced amount of carbohydrates (Sánchez-Muros et al., 1998; Capilla et al., 2003; Polakof et al., 2008b,c) or after IP or ICV hypoglycaemic treatments (Polakof et al., 2007a, 2008a; Conde-Sieira et al., 2010a,b). Comparable responses of food intake to changes in glucose levels also occurred in other fish species including goldfish (Narnaware and Peter, 2002), tilapia (Saravanan et al., 2012; Figueiredo-Silva et al., 2013), Siberian sturgeon (Gong et al., 2014) or sea bass (Castro et al., 2015).

In brain areas producing AgRP/NPY and POMC/CART histochemical studies in rainbow trout support the presence of GK (Polakof et al., 2009) suggesting a functional relationship between glucosensors and neuropeptides. However, few studies in fish described changes in the mRNA abundance of those neuropeptides in response to changes in glucose levels. The mRNA abundance of hypothalamic NPY decreased in hyperglycaemic-treated rainbow trout (Conde-Sieira et al., 2010b, 2012b; Aguilar et al., 2011; Otero-Rodiño et al., 2016a).
A similar decline occurred in fish fed with a carbohydrateenriched diet, such as in rainbow trout (Figueiredo-Silva et al., 2012c) and goldfish (Narnaware and Peter, 2002) whereas in the whole brain of gilthead sea bream no changes occurred (Babaei et al., 2017). CART mRNA levels in hypothalamus increased in response to elevated glucose levels in catfish (Subhedar et al., 2011) and rainbow trout (Conde-Sieira et al., 2010b, 2012b; Otero-Rodiño et al., 2015) or after rainbow trout were fed with a carbohydrate-enriched diet (Figueiredo-Silva et al., 2012c). Hypothalamic POMC mRNA levels increased in hyperglycaemic rainbow trout (Conde-Sieira et al., 2010b; Otero-Rodiño et al., 2015). Finally, AgRP mRNA abundance did not display changes in hypothalamus of rainbow trout after hyperglycaemic treatment (Otero-Rodiño et al., 2015, 2016a). Therefore, the mRNA abundance in glucosensing central areas (hypothalamus and hindbrain) of the four neuropeptides involved in the food intake regulation is affected by changes in glycaemia, and this is compatible with the changes observed in food intake (Polakof et al., 2008a,b).

\section{Fatty Acid Sensors and Regulation of Food Intake}

In fish fed with a lipid-enriched diet, a decrease in food intake usually takes place. This occurred for instance in rainbow trout (Peragón et al., 2000; Rasmussen et al., 2000; Gélineau et al., 2001; Forsman and Ruohonen, 2009; Figueiredo-Silva et al., 2012c; Saravanan et al., 2013), chinook salmon (Silverstein et al., 1999), polka-dot grouper (Williams et al., 2006), Senegalese sole (Bonacic et al., 2016) or grass carp (Li et al., 2016). Moreover, enhanced lipid storage is also usually associated with a reduced food intake (Shearer et al., 1997; Silverstein et al., 1999; Johansen et al., 2002, 2003). Therefore, lipid metabolism is clearly influencing food intake control in fish. Considering the relative high importance of fatty acids within the lipid pool, both in fish diets and in tissue composition, is not surprising that the available studies in fish focussed on fatty acids.

In recent studies in rainbow trout a decrease in food intake was observed after IP (Librán-Pérez et al., 2012) or ICV (LibránPérez et al., 2014a; Velasco et al., 2016a,b) administration of oleate or octanoate, with the effect being more important for octanoate. The effect of octanoate is specific of fish (at least rainbow trout) since in mammals treatment with this fatty acid did not affect food intake (López et al., 2007; Hu et al., 2011). Moreover, when rainbow trout fed diets containing different lipid composition, the lower food intake occurred in fish with the highest levels of fatty acid in plasma (Luo et al., 2014). This finding supports that central fatty acid sensing mechanisms mediated the lipid-induced decrease in food intake. Further support come from results obtained in rainbow trout where the decrease in food intake induced by treatment with a fatty acid synthase (FAS) inhibitor is counteracted by the simultaneous presence of an acetyl-CoA carboxylase inhibitor (Librán-Pérez et al., 2012), i.e., a response similar to that of mammals (Loftus et al., 2000; Gao and Lane, 2003; Hu et al., 2011). In Senegalese sole IP treatment with oleate, $\alpha$-linolenate, or eicosapentanoate also resulted in a decrease in food intake (Conde-Sieira et al., 
2015a). Furthermore, when levels of circulating fatty acid decreased through pharmacological treatment a clear increase in food intake occurred in rainbow trout (Librán-Pérez et al., 2014b).

In mammals, the activation of fatty acid sensing systems results in food intake inhibition through changes in the expression of anorexigenic and orexigenic neuropeptides (López et al., 2005; Oh et al., 2016). Accordingly, the increase in LCFA levels results in a decrease in the mRNA abundance of AgRP and NPY as well as in an increase in mRNA abundance of CART and POMC. Therefore, not surprisingly, several studies have described changes in mRNA abundance of neuropeptides in fish fed lipid-enriched diets. Feeding fish with these diets resulted in increased mRNA abundance of POMC in rainbow trout (LibránPérez et al., 2015b), and increased mRNA abundance of CART in rainbow trout (Figueiredo-Silva et al., 2012c; Librán-Pérez et al., 2015b) and Atlantic salmon (Hevrøy et al., 2012). Feeding diets enriched in lipids also induced a decrease in NPY mRNA abundance in grass carp ( $\mathrm{Li}$ et al., 2010) but not in rainbow trout (Figueiredo-Silva et al., 2012c; Librán-Pérez et al., 2015b) or orange-spotted grouper (Tang et al., 2013). Finally, AgRP mRNA abundance did not change in Atlantic salmon (Hevrøy et al., 2012) but decreased in rainbow trout (Librán-Pérez et al., 2015b) fed with lipid-enriched diets.

Other available studies described the impact of treatments with specific fatty acids on mRNA abundance of orexigenic and anorexigenic neuropeptides. In rainbow trout oleate either through IP (Librán-Pérez et al., 2012), in vitro (Librán-Pérez et al., 2013c) or ICV (Librán-Pérez et al., 2014a; Velasco et al., 2016a,b) treatments resulted in hypothalamus in a decrease in mRNA abundance of NPY and an increase in mRNA abundance of CART and POMC. Changes observed in NPY mRNA levels after oleate treatment are comparable to those of mammals (Blouet and Schwartz, 2010). The changes displayed by neuropeptides point to an enhancement of the anorexigenic potential, which is in agreement with the effects in food intake after treatment with the same fatty acid. The treatment of rainbow trout with octanoate also resulted in decreased NPY mRNA abundance after ICV treatment (Librán-Pérez et al., 2014a), and increased mRNA abundance of CART and POMC after ICV and in vitro treatments (Librán-Pérez et al., 2013c, 2014a). These changes also suggest an enhancement of the anorexigenic potential in hypothalamus in response to octanoate treatment supporting the reduced food intake observed after treating the same species with octanoate (Librán-Pérez et al., 2012, 2014a). This effect of octanoate is exclusive to fish, at least rainbow trout, since in mammals octanoate does not induce any change in mRNA abundance of neuropeptides ( $\mathrm{Hu}$ et al., 2011). In Senegalese sole, the treatment with oleate also induced a decrease in the mRNA abundance of AgRP while that of CART increased, i.e., a balance favoring an anorexigenic response (Conde-Sieira et al., 2015a). In the same species, the IP treatment with the PUFAs $\alpha$-linolenate or eicosapentanoate (Conde-Sieira et al., 2015a) decreased mRNA abundance of AgRP ( $\alpha$-linolenate) and increased mRNA abundance of CART ( $\alpha$-linolenate and eicosapentanoate) thus favoring enhanced anorexigenic potential, in a way similar to the effects elicited by oleate. This was the first time in any vertebrate species in which any PUFA induced changes in hypothalamic mRNA abundance of neuropeptides involved in food intake control. Interestingly, parameters involved in fatty acid sensing changed only in the case of $\alpha$-linolenate (Conde-Sieira et al., 2015a) suggesting a complex relationship between changes in fatty acid sensing and neuropeptide mRNA abundance.

In a way similar to that described above for fatty acid sensing systems and food intake responses, the decrease in rainbow trout of circulating levels of fatty acid resulted in decreased mRNA abundance of POMC and CART. This change favors enhanced orexigenic potential (Librán-Pérez et al., 2014b), i.e., the opposed response of that elicited by increased levels of fatty acids.

\section{Linking Nutrient Sensing and Neuropeptide Control of Food Intake}

The mechanisms linking the function of nutrient sensing systems with changes in the expression of neuropeptides, which ultimately regulate food intake, are mostly unknown in mammals. Changes in the expression of neuropeptides might relate to modulation of forkhead box01, phosphorylated cAMP response-element binding protein, and/or brain homeobox transcription factor (Diéguez et al., 2011). The actions of these factors would result in the enhancement of CART and POMC expression and the inhibition of AgRP and NPY expression resulting in decreased food intake (López et al., 2007; Diéguez et al., 2011). However, it is not clear how these transcription factors relate to the activity of the different nutrient sensing systems. Several possibilities have been suggested in mammals (López et al., 2007; Diéguez et al., 2011; Gao et al., 2013; Morton et al., 2014) including direct action of malonyl CoA or CPT-1, indirect action through CPT-1 inhibition, modulation by AMPK, mTOR, protein kinase B (Akt), or carbohydrate-responsive element-binding protein and/or involvement of ceramides.

In fish, several recent studies carried out in rainbow trout provided evidence for several of these hypothetical mechanisms. Indeed, Librán-Pérez et al. (2015b) demonstrated that protein levels of AMPK, Akt, and mTOR increased in hypothalamus of fish fed a lipid-enriched diet. Furthermore, Gong et al. (2016a) demonstrated increased Akt protein levels in isolated hypothalamic cells incubated with leptin. Finally, Velasco et al. (2016b) also suggested the possible involvement of ceramides in the connection between activation of hypothalamic fatty acid sensing systems, neuropeptide mRNA abundance, and control of food intake. Besides these preliminary studies, there is no other evidence in fish about hypothalamic pathways related to integration of metabolic information coming from different nutrient sensor systems (glucose, fatty acids, amino acids) into a shared pathway controlling food intake via neuropeptide expression.

Food intake regulation is a complex process in which nutrient sensing systems are apparently involved in fish, in a way again comparable to that of mammals with notable differences including the capacity of several nutrients like MCFA or PUFA to modify food intake control in fish. Again, there is no information regarding the involvement of amino acid sensing systems in fish 
on food intake regulation, and this clearly needs assessment in the near future. Once characterized such a putative effect, the next step would be the assessment of how and why changes in those sensing systems translate into expression of anorexigenic and orexigenic neuropeptides ultimately regulating food intake. The possible mechanisms are mostly unknown, even in mamamals, and therefore it is quite probable that important differences between fish and mammals arise considering their different gastrointestinal morphology and physiology, and dietary habits.

\section{IMPACT OF NUTRIENT SENSING ON ENERGY HOMEOSTASIS}

Nutrient sensing mechanisms in mammals are also implicated in the regulation of energy homeostasis through processes other than food intake (Levin, 2006; Blouet and Schwartz, 2010; Morton et al., 2014), such as hormone secretion and energy expenditure (Morgan et al., 2004; Pocai et al., 2005; Le Foll et al., 2009; Roh et al., 2016). The homeostatic control carried out by nutrient sensing systems occurs at both central and peripheral levels. At the central level, the brain integrates multiple metabolic inputs from the periphery as nutrients, gutderived satiety signals and adiposity-related hormones eliciting a counter-regulatory response in peripheral tissues modulating various aspects of metabolism (Morton et al., 2014; Rogers et al., 2016). At peripheral level, nutrient sensing systems modulate energy metabolism either directly or indirectly through endocrine effectors (Marty et al., 2007; Morton et al., 2014).

\section{Central Nutrient Sensing and Counter-Regulation Central Nutrient Sensing and Regulation of Hepatic Metabolism}

ICV administration of glucose or a LCFA like oleate in mammals results in a decrease of hepatic glucose production and lipogenesis (Obici et al., 2002; Morgan et al., 2004; Migrenne et al., 2011). The downstream mechanism(s) involved are presumably based on sympathetic and parasympathetic systems that provide direct innervations to liver and endocrine pancreas via the splanchnic nerve and vagus nerve, respectively (Morgan et al., 2004; Migrenne et al., 2006; Blouet and Schwartz, 2012; Roh et al., 2016).

In fish, central glucose administration affects liver metabolism. In rainbow trout ICV administration of glucose resulted in liver in decreased levels of glucose and glucose 6-phosphate, increased capacity for glycolysis and glycogenesis, and decreased capacity of glucose export into plasma (Polakof and Soengas, 2008). The presence of glucose in the brain appears to be a signal of energy abundance indicative that no production and release of glucose from liver is necessary to sustain plasma glucose levels (Polakof and Soengas, 2008). Central treatment with oleate or octanoate in rainbow trout also induced changes in several parameters related to fatty acid and glucose metabolism in liver directed to counter-regulate the elevated fatty acid levels detected in the brain (Librán-Pérez et al., 2015c). These changes in liver include increased levels of glucose and glycogen, decreased levels of fatty acids and total lipids, decreased mRNA abundance of GK and fructose 1,6-bisphosphatase as well as FAS and CPT-1 activities. The changes in glucose metabolism observed in liver are similar to those reported in mammals where ICV administration of oleate (but not octanoate) resulted in a marked decrease of hepatic glucose production via decreased glycogenolysis and glucose release (Obici et al., 2002; Morgan et al., 2004). Furthermore, the results obtained in liver metabolism were similar when comparing central (Librán-Pérez et al., 2015c) and IP (LibránPérez et al., 2013b) administration of fatty acid, which would indicate that sensing capacity in liver is indirect and therefore dependent on the previous sensing in brain. These changes in hepatic metabolism after central administration of glucose or fatty acid are indicative of a functional connection between central nutrient sensing and production/release of fuels from liver (Marty et al., 2007). The mechanisms involved are also likely based on sympathetic and parasympathetic systems (Morgan et al., 2004; Migrenne et al., 2006) since, at least in rainbow trout, vagus and splanchnic nerves are present in the gastrointestinal tract though it is not clear whether or not branches of those nerves arrive to the liver (Burnstock, 1959; Seth and Axelsson, 2010).

Interestingly, in rainbow the HPI axis is also likely involved in the counter-regulatory response of liver metabolism to a fall of circulating FA levels, in order to restore the normal values (Librán-Pérez et al., 2014b, 2015d), in a way comparable to that described in mammals (Oh et al., 2012, 2014).

\section{Central Nutrient Sensing and the Pancreatic Counter-Regulatory Response}

Central glucose detection is involved in mammals in the pancreatic counter-regulatory response to hypoglycaemia in order to restore normal blood glucose levels (Blouet and Schwartz, 2010). The brain, especially the hypothalamus and brain stem, receives and integrates this information to control the counter-regulatory response by modulating pancreatic insulin and glucagon secretion via the parasympathetic and sympathetic efferent nerves that innervate pancreatic $\alpha$ - and $\beta$-cells (Ogunnowo-Bada et al., 2014; Roh et al., 2016). This response involves suppression of insulin secretion, activation of glucagon secretion, activation of catecholamine secretion from the adrenal glands, and the activation of hepatic glucose production by the autonomic nervous system (Marty et al., 2007). Conversely, central glucose administration suppresses the counter-regulatory hormonal responses to hypoglycaemia (Roh et al., 2016). In mammals, several studies demonstrate the involvement of central glucosensors and their components in the counter-regulatory response (Miki et al., 2001; Evans et al., 2004; Sanders et al., 2004; Marty et al., 2005; McCrimmon et al., 2005). These central glucosensors can modulate not only the counter-regulatory response to hypoglycaemia in the pancreatic cells by modulating the glucagon secretion, but also the glucosestimulated insulin secretion in the $\beta$-cells, through activation and inhibition of the sympathetic or parasympathetic branches, respectively (Thorens, 2011; Chan and Sherwin, 2012; Osundiji et al., 2012). 
In fish, central administration of glucose in rainbow trout resulted in increased GK activity and expression in BB (Polakof and Soengas, 2008). This may suggest an activation of the glucosensor system in BB that could result in increased insulin levels in plasma as part of the system trying to counter-regulate the increase in plasma glucose levels elicited by ICV treatment (Polakof and Soengas, 2008). Other studies carried out in rainbow trout also support the connection between glucose levels and pancreatic function (Polakof et al., 2012a,b). Indeed, plasma insulin levels decrease and plasma glucagon levels increase in fish subjected to natural or experimental deprivation of food (Navarro and Gutiérrez, 1995). Moreover, in zebrafish exposed to high glucose levels, insulin expression was also apparently enhanced (Jurczyk et al., 2011).

Several studies in mammals suggest that not only glucose, but also fatty acid detection in central nutrient sensing areas can alter the pancreatic function through alterations of sympathetic nervous activity (Migrenne et al., 2006; Blouet and Schwartz, 2010). Central administration of lipids that do not change plasma fatty acid concentrations, induce increased glucoseinduced insulin secretion counteracted by the inhibition of $\beta$-oxidation (Cruciani-Guglielmacci et al., 2004). Furthermore, oleate injection leads to increments in plasma insulin levels without altering glycaemia, suggesting that fatty acids per se can regulate neural control of insulin secretion (Migrenne et al., 2011).

In fish, ICV treatment with oleate or octanoate elicited several changes in BB lipid metabolism (Librán-Pérez et al., 2015c), which, in general, are different than those obtained after IP administration using the same fatty acid (Librán-Pérez et al., 2012) or to those described in mammals after ICV administration of oleate (MacDonald et al., 2008). Therefore, contrary to that observed in mammals, fatty acid sensing in BB of rainbow trout appears to be mainly direct and probably not dependent on previous central sensing. Furthermore, the action of peripheral hormones is probably influencing sensing capacity since results obtained after IP administration of fatty acid in vivo differed from those obtained with the same tissue in vitro (Librán-Pérez et al., 2013a).

\section{Peripheral Nutrient Sensing and Energy Homeostasis \\ Metabolic Response of Liver to Changes in Nutrient Abundance}

In fish, as in mammals, the regulation of glucose levels in blood depends on the balance between glucose utilization via glycolysis or glycogenesis, and glucose production via gluconeogenesis or glycogenolysis in liver. An imbalance in this regulation could be responsible of glucose intolerance in some fish species (Enes et al., 2009; Polakof et al., 2012a). This regulation relies on the differential response to variations in glycaemia of enzymes involved in hepatic metabolism. GK has been shown to be essential in fish liver for induction by glucose of key glycolytic and lipogenic enzymes and repression of genes involved in gluconeogenesis (Vaulont et al., 2000) thus acting as a glucosensor (Magnuson and Matschinsky, 2004; Polakof et al., 2011d). Thus, many fish species increased GK activity and/or expression as well as glycolytic potential in liver under hyperglycaemic conditions induced by glucose administration or by feeding diets with high contents of carbohydrates (Tranulis et al., 1996; Panserat et al., 2000; Enes et al., 2006, 2009; CondeSieira et al., 2010a, 2015b, 2016; Castro et al., 2016).

Changes in circulating levels of glucose also modulated other components of the GK-dependent glucosensing machinery in liver of different fish species (Hemre et al., 2002; Polakof et al., 2008b, 2011d; Enes et al., 2009). These include variations in glucose and glycogen levels, GLUT2 mRNA abundance, glycolytic and glycogenic potentials, and in the activity of $\mathrm{K}_{\mathrm{ATP}}^{+}$ occurred in the liver of hyperglycaemic rainbow trout (CondeSieira et al., 2010a, 2012a). Moreover, in rainbow trout fed a carbohydrate-enriched diet an up-regulation occurred in these parameters while feeding a carbohydrate-free diet resulted in a down-regulation (Polakof et al., 2008b). As for GK-independent mechanisms, experimental results obtained in fish liver indicate enhanced mitochondrial activity in response to increased levels of glucose in rainbow trout (Craig et al., 2013; Otero-Rodiño et al., 2016b). However, these responses were not reflected in other fish species such as zebrafish (Seiliez et al., 2013), red sea bream (Liang et al., 2003) or grass carp (Li et al., 2010). Furthermore, experiments in vitro carried out in rainbow trout did not confirm the presence of a glucosensing mechanism in liver mediated by the mitochondrial activity (Otero-Rodiño et al., 2016c). The mechanism based on sweet taste receptor appears to be operative in liver of rainbow trout since the responses obtained with this tissue in vitro (Otero-Rodiño et al., 2016c) are compatible with the responses described in mammalian liver (Treesukosol et al., 2011) although with some differences to those presented in vivo (Otero-Rodiño et al., 2016b). A glucosensor based on the hepatic LXR seems to work differentially in fish liver compared with mammals since gluconeogenesis is not inhibited by hyperglycaemia either induced by glucose administration or by feeding fish with carbohydrate-enriched diets (Panserat et al., 2001; Kirchner et al., 2008; Polakof et al., 2011d; Otero-Rodiño et al., 2016b,c). However, in other fish species such as Senegalese sole, gilthead sea bream or common carp a clear inhibition of gluconeogenesis occurred under hyperglycaemic conditions (Panserat et al., 2002b; Kamalam et al., 2013; Conde-Sieira et al., 2015b, 2016) although no studies regarding glucosensing mechanisms based on LXR are available in these species.

Other metabolic sensors regulate intermediary metabolism in mammals through control of intracellular glucose use (Polakof et al., 2012a), including AMPK (activated when the energy level in the cell is low) or mTOR (activated when the levels of nutrients increase). In fish, AMPK phosphorylation decreased in liver and mTOR phosphorylation increased in liver and muscle of rainbow trout under post-prandial conditions (Seiliez et al., 2008; Lansard et al., 2010; Polakof et al., 2011e). Furthermore, the pharmacological activation of hepatic AMPK and the inhibition of mTOR pathway induce glucose catabolism and increased gluconeogenesis besides decreased glycolysis in trout liver, respectively (Lansard et al., 2010; Polakof et al., 2011e). These findings suggest the existence in fish of a system induced by feeding carbohydrates with similar consequences 
on glucose metabolism as those observed in mammals (Seiliez et al., 2008; Lansard et al., 2010; Polakof et al., 2011e). Moreover, under hyperglycaemic conditions a decrease in the mRNA abundance of sirtuin-1 (another integrative nutrient sensor) is observed in liver and BB of rainbow trout (Otero-Rodiño et al., 2016b), similar to that described in mammals (Ruderman et al., 2010; Velásquez et al., 2011). Therefore, evidences exist in fish regarding the functioning of integrative energy and nutrient sensors in response to changes in the levels of a nutrient like glucose (Otero-Rodiño et al., 2016b).

Increased circulating fatty acid levels also induce metabolic changes in liver of fish as in mammals, in order to restore normal conditions. High content of lipids in the diet reduce lipogenic potential and increases $\beta$-oxidation in the liver of many fish species (Dias et al., 2004; Figueiredo-Silva et al., 2010; Borges et al., 2013; He et al., 2015; Librán-Pérez et al., 2015b; Li et al., 2016). Furthermore, dietary lipid level affects glucose metabolism inducing hyperglycaemia, and reducing glycolytic capacity and increasing gluconeogenic potential in liver, as described in several fish species like rainbow trout (Gélineau et al., 2001; Panserat et al., 2002a; Figueiredo-Silva et al., 2012a,b), other salmonids (Mazur et al., 1992; Hemre and Sandnes, 1999), grouper (Cheng et al., 2006), sunshine bass (Hutchins et al., 1998), and Senegalese sole (Borges et al., 2014). The long-term use of lipid-enriched diets in fish can compromise glucose homeostasis due to an impairment on insulin signaling and a down regulation of the Akt and mTOR pathways, as observed in rainbow trout or Senegalese sole (Panserat et al., 2002a; Figueiredo-Silva et al., 2012b; Borges et al., 2014).

Several of the putative components of fatty acid sensing mechanisms are present in fish liver (Kolditz et al., 2008; PlagnesJuan et al., 2008; Lansard et al., 2009; Skiba-Cassy et al., 2009; Polakof et al., 2010b). Moreover, the peripheral administration of oleate or octanoate induces in rainbow trout enhanced fatty acid catabolism as well as reduced lipogenic and glycolytic potentials, suggesting a direct action of fatty acid administration on hepatic glucose and lipid metabolism (Librán-Pérez et al., 2013b). However, under in vitro conditions (Librán-Pérez et al., 2013c), administration of oleate or octanoate induces changes opposed of those observed in vivo, which indicates that fatty acid sensing capacity in liver is indirect and probably be the result of previous hypothalamic sensing. The finding that ICV treatment in rainbow trout with the same fatty acid induced changes in fatty acid sensing systems (Librán-Pérez et al., 2015c) similar to those obtained after IP treatment supports this hypothesis.

\section{Nutrient Sensing in BB and the Modulation of Hormone Release}

In mammals, the glucosensing mechanism based on GK present in pancreatic $\beta$-cells is involved in modulation of insulin release in response to changes in blood glucose levels (Rutter et al., 2015), which therefore constitutes an essential mechanism for the maintenance of glucose homeostasis (MacDonald et al., 2005; Polakof et al., 2011d).

Experimental evidences suggest that a glucosensor system linked to insulin secretion is present in pancreatic endocrine cells in fish. Indeed, insulin release is stimulated by glucose
(Epple et al., 1987; Mommsen and Plisetskaya, 1991; Hrytsenko et al., 2008; Jurczyk et al., 2011) as well as by 2-deoxyglucose, mannose and $\mathrm{K}^{+}$(Ronner and Scarpa, 1987; Ronner, 1991) and inhibited under hypoglycaemia induced by food deprivation (Navarro and Gutiérrez, 1995). These changes may relate to those observed in the pancreatic glucosensor system in fish under altered conditions of glycaemia. In rainbow trout BB these include increased GK activity and expression, GLUT2 expression, glycolytic capacity as well as glucose and glycogen levels in hyperglycaemic fish (Polakof et al., 2007a,b). In the same species, feeding fish with diets enriched in carbohydrates upregulates glucosensing response in $\mathrm{BB}$ whereas feeding fish with diets poor in carbohydrates resulted in a down-regulation of glucosensing response in the same tissue (Polakof et al., 2008b,c). Some GKindependent mechanisms also present in $\mathrm{BB}$ of rainbow trout respond to increased levels of glucose with changes in parameters related to mitochondrial activity, LXR, and sweet taste receptor both in vivo (Otero-Rodiño et al., 2016b) and in vitro (OteroRodiño et al., 2016c).

In mammals, lipid metabolism in the $\beta$-cell is also critical for the normal regulation of insulin secretion (MacDonald et al., 2008) and fatty acids directly regulate insulin release from pancreatic $\beta$-cells (Nolan et al., 2006). In fish, the available experimental results also demonstrate enhanced insulin release in response to increase levels of fatty acid (Barma et al., 2006). Moreover, insulin treatment in rainbow trout enhances the potential of lipogenesis and decreases the potential of fatty acid oxidation in several tissues (Plagnes-Juan et al., 2008; Lansard et al., 2010; Polakof et al., 2010b, 2011d; Caruso and Sheridan, 2011). In rainbow trout, the decreased mRNA levels of FAS and CPT1c in BB after treatment with oleate or octanoate (LibránPérez et al., 2012) suggest that components of putative fatty acid sensing systems respond in BB to increased fatty acid levels. This response could modulate insulin secretion from this tissue, as reported in mammals (Keane and Newsholme, 2014), with the main difference that in fish fatty acid sensing systems are also responsive to a MCFA like octanoate. This mechanism appear to be mainly the result of a direct action of fatty acid in $\beta$-cells (Librán-Pérez et al., 2013a) though an indirect action by previous hypothalamic sensing mediated by vagal and/or splanchnic outflow cannot be discarded (Librán-Pérez et al., 2015c).

\section{Glucosensing Capacity in Gut}

The gastrointestinal tract in mammals has an important role in the complex signaling network that controls food intake, metabolism and energy homeostasis since it releases several energy-related gastrointestinal hormones that send nutritional information to the control areas in the brain through afferent nerves (Schwartz et al., 2000; Roh et al., 2016). Accordingly, the presence of nutrient sensing mechanisms have been proposed in mammalian enteroendocrine cells (Miguel-Aliaga, 2012) and enterocytes (Pfannkuche and Gäbel, 2009). Glucose can be sensed in the gastrointestinal tract by mechanisms dependent on sweet taste receptors and gustducin, which are activated by glucose leading to the release of glucagon-like peptide 1 (GLP-1) and gastric inhibitory polypeptide (Kokrashvili et al., 
2009; Miguel-Aliaga, 2012). Other glucosensing mechanisms controlling hormonal release in mammalian gastrointestinal tract involve electrogenic or metabolic processes mediated by SGLT-1 and GLUT2/GK (Miguel-Aliaga, 2012).

In fish intestine, histochemical studies evidence the presence of components of different glucosensing systems (SGLT-1 and GK) in enterocytes and enteroendocrine cells of rainbow trout (Polakof et al., 2010a). Furthermore, molecular evidence also pointed to the presence in fish intestine of glucosensing mechanisms involving components of metabolic (GK/GLUT2), electrogenic (SGLT-1), nuclear (LXR) and sweet taste receptor systems (Ishimaru et al., 2005; Geurden et al., 2007; Hashiguchi et al., 2007; Kirchner et al., 2008; Cruz-García et al., 2009; Polakof et al., 2010a). However, only few studies characterized the response of these systems in intestine to increased levels of glucose. In black bullhead enterocytes enhanced glucose uptake through SGLT-1 occurred in fish fed a diet rich in carbohydrates (Soengas and Moon, 1998) whereas in zebrafish GLUT2 mRNA abundance in intestine changed in parallel with changes in glucose levels (Castillo et al., 2009). In rainbow trout, increased glycogen levels, GK activity, glycolytic capacity, and transcript levels of GK, SGLT-1, and LXR, as well as decreased transcript levels of T1R and gustducin occurred in intestine of hyperglycemic trout (Polakof et al., 2010a; Polakof and Soengas, 2013). These systems seem to operate in fish in a different way compared with other vertebrate species (Polakof and Soengas, 2013) but certainly appear to be functional, and thus presumably involved in fish gastrointestinal physiology, especially through production and release of gastrointestinal hormones.

\section{Possible Glucosensing Capacity in Head Kidney and Its Role on Cortisol Release}

One study using head kidney perifused cultures in rainbow trout demonstrated that in the presence of $\mathrm{ACTH}$, cortisol release increased in parallel with the increase of glucose in the medium (Conde-Sieira et al., 2013). These changes could relate to the presence of a glucosensing system in putative interrenal cells in head kidney that would respond to glucose levels in a way similar to that of pancreatic $\beta$-cells for insulin release. Accordingly, immunohistochemical studies indicate the presence of GK protein in interrenal cells and SGLT-1 protein in both interrenal and chromaffin cells of rainbow trout (Conde-Sieira et al., 2013). However, metabolite levels and enzymes activities involved in glucosensing mechanisms did not show a clear response to changes in circulating glucose levels in head kidney of rainbow trout, probably due to the high cellular heterogeneity of the tissue assessed (Conde-Sieira et al., 2013). A further study in rainbow trout (Gesto et al., 2014) supports that cortisol release under stress conditions in rainbow trout might relate to hyperglycemia previously elicited by catecholamine action.

As a whole, the nutrient sensing systems characterized in fish are involved in the regulation of energy homeostasis through mechanisms other than regulation of food intake. The evidence obtained in recent years pointed to a role of these systems in counter-regulatory mechanisms as well as in the regulation of hormone release, though the evidence is preliminary in some cases.

\section{ENDOCRINE MODULATION OF NUTRIENT SENSING}

Several hormones modulate the response of nutrient sensing systems in mammals to changes in the levels of nutrients. These hormones provide information about homeostasis, status of energy stores, and the presence of food and its composition in the gastrointestinal tract. These include ghrelin, insulin, leptin, cholecystokinin (CCK), GLP-1, adiponectins, cannabinoids, and glucocorticoids (Diéguez et al., 2009; Blouet and Schwartz, 2010; Morton et al., 2014).

Results obtained in recent years in fish provide evidence for the modulatory role of several of these hormones in the activity of nutrient sensing systems as well as in the mRNA abundance of neuropeptides related to the control of food intake. Moreover, several of these hormones modulate peripheral nutrient sensing systems.

As in other vertebrates, insulin administration modifies glucose and lipid metabolism in fish, by enhancing the glucose uptake in liver and muscle, increasing hepatic glycolytic and lipogenic potentials, and depressing gluconeogenesis and fatty acid oxidation (Mommsen and Plisetskaya, 1991; Plagnes-Juan et al., 2008; Jin et al., 2014). The effects on lipid metabolism depend on the dose of insulin administered as well as the feeding status of fish (Polakof et al., 2010b, 2011f). Insulin is present and synthesized in fish brain (Caruso et al., 2008) where insulin receptors are also present (Gutiérrez and Plisetskaya, 1994; Leibush et al., 1996). Insulin treatment resulted in contradictory effects in food intake in fish. In rainbow trout IP administration of insulin inhibited (Librán-Pérez et al., 2015a) or activated (Polakof et al., 2008a; Conde-Sieira et al., 2010b) food intake whereas ICV treatment with insulin inhibited food intake in rainbow trout (Soengas and Aldegunde, 2004) but not in catfish (Silverstein and Plisetskaya, 2000). The putative anorectic effects of insulin would be in agreement with the increased anorexigenic potential elicited by insulin treatment as demonstrated increased mRNA abundance of CART in rainbow trout (Librán-Pérez et al., 2015a) and catfish (Subhedar et al., 2011) as well as decreased NPY mRNA abundance in rainbow trout (LibránPérez et al., 2015a). As for insulin capacity to modulate the activity of nutrient sensing systems, its administration in rainbow trout inhibits glucosensing response in hypothalamus, hindbrain, BB, and intestine (Polakof et al., 2007a, 2008a, 2010b; Conde-Sieira et al., 2010b). As for fatty acid sensing systems, no clear effects of insulin treatment were observed in rainbow trout hypothalamus (Librán-Pérez et al., 2015a), in contrast to mammals (Duca and Yue, 2014). However, in liver and $\mathrm{BB}$ insulin treatment potentiates the effect of oleate and octanoate on fatty acid sensing systems (Librán-Pérez et al., 2015a).

Leptin treatment is usually anorectic in fish as demonstrated studies in rainbow trout (Murashita et al., 2008; Kling et al., 2009; Aguilar et al., 2010; Gong et al., 2016a), goldfish (Volkoff et al., 2003; de Pedro et al., 2006; Vivas et al., 2011) and striped bass (Won et al., 2012). This anorectic effect occurred in parallel with changes in the expression of neuropeptides generally indicating an enhanced anorexigenic potential. Thus, 
leptin treatment induced a decrease in NPY mRNA levels in hypothalamus of rainbow trout (Murashita et al., 2008; Aguilar et al., 2011), hypothalamus and telencephalon of goldfish (Volkoff et al., 2003), and in whole brain in grass carp (Li et al., 2010). POMC mRNA abundance increased in response to leptin treatment in rainbow trout (Murashita et al., 2008; Aguilar et al., 2011; Gong et al., 2016a). Leptin treatment also increased CART mRNA levels in hypothalamus of goldfish (Volkoff and Peter, 2001), catfish (Subhedar et al., 2011), and rainbow trout (Murashita et al., 2008; Aguilar et al., 2011; Gong et al., 2016a). Furthermore, leptin receptor knockout for medaka displayed (compared with the wild type) a higher food intake, as well as decreased POMC mRNA abundance, and increased NPY and AgRP mRNA abundance (Chisada et al., 2014) whereas zebrafish knockout for leptin displayed changes in mRNA abundance of genes related to glucose but not to lipid metabolism (Michel et al., 2016). The anorectic effects of leptin could relate, at least in part, to the activation of nutrient sensing systems. In fact, leptin treatment clearly activates central glucosensing systems in rainbow trout (Aguilar et al., 2010, 2011). There is little evidence for the action of leptin on nutrient sensing systems in peripheral tissues of fish. The only available study showed that ICV leptin treatment in rainbow trout did not affect liver glucosensing capacity, although an increased glycogenolytic potential possibly mediated by the activation of the sympathetic nervous system occurred in rainbow trout liver (Aguilar et al., 2010).

Few studies have assessed the effects of GLP-1 on food intake in fish to date. GLP-1 treatment resulted in an inhibition of food intake in catfish (Silverstein et al., 2001) and coho salmon (White et al., 2016) but not in channel catfish (Schroeter et al., 2015). In rainbow trout GLP-1 treatment (Polakof et al., 2011b) elicited in hypothalamus and hindbrain the activation of glucosensing systems with increased mRNA abundance of CART and POMC, and decreased mRNA abundance of NPY, i.e., changes clearly indicative of enhanced anorexigenic potential. In the same species, GLP-1 IP treatment also resulted in the activation of GK-mediated glucosensing mechanism in liver (Polakof et al., 2011b).

Treatments with CCK produce anorectic responses in fish as demonstrated in rainbow trout (Gélineau and Boujard, 2001; Jönsson et al., 2006), coho salmon (White et al., 2016), goldfish (Himick and Peter, 1994; Kang et al., 2010), catfish (Silverstein and Plisetskaya, 2000), sea bass (Rubio et al., 2008), and winter flounder (MacDonald and Volkoff, 2009). Furthermore, CCK treatment in rainbow trout activated glucosensing capacity in hypothalamus and hindbrain (Polakof et al., 2011a), and this is accompanied by decreased NPY mRNA levels in hindbrain and hypothalamus, thus supporting increased anorexigenic potential. In liver of rainbow trout IP administration of CCK also activated glucosensing capacity (Polakof et al., 2011a).

The effects of ghrelin treatment on food intake in fish are controversial. Increases were noted in goldfish (Miura et al., 2006), brown trout (Tinoco et al., 2014), rainbow trout (Velasco et al., 2016a,b), striped sea bass (Picha et al., 2009) or cavefish (Penney and Volkoff, 2014) whereas decreases occurred in rainbow trout (Jönsson et al., 2010), channel catfish (Schroeter et al., 2015), and tilapia (Peddu et al., 2009). In rainbow trout ghrelin treatment activates central glucosensing systems (Polakof et al., 2011c), an effect opposed of that in mammals (Wang et al., 2008). In contrast ghrelin treatment induces an inhibition of fatty acid sensing systems in rainbow trout hypothalamus and hindbrain (Velasco et al., $2016 \mathrm{a}, \mathrm{b})$ in a way similar to that described in mammals, and these changes agree with those of mRNA abundance of neuropeptides that decreased for POMC/CART and increased for AgRP/NPY. Increased mRNA abundance of NPY occurred in hypothalamus of ghrelin-treated goldfish (Miura et al., 2006). Central ghrelin treatment also modulates indirectly hepatic liver metabolism resulting in increased potential for lipogenesis and decreased potential for fatty acid oxidation, as indicative of inhibition of fatty acid sensing (Velasco et al., 2016c).

A reduction in food intake is a typical response to stress in fish, and at least part of this response might depend on changes in the ability of stress to alter nutrient sensing systems regulating food intake. A readjustment in the activity of hypothalamic glucosensing mechanisms occurred in stressed rainbow trout (Conde-Sieira et al., 2010a; Otero-Rodiño et al., 2015). This effect might relate to any of the components of the HPI axis such as corticotropin releasing factor (CRF), which is involved in the effects of stress on food intake in mammals (Evans et al., 2004; McCrimmon et al., 2006). Accordingly, the treatment of rainbow trout hypothalamus with CRF altered functioning of glucosensing mechanisms (Conde-Sieira et al., 2011) in a way similar to that observed under stress conditions (Conde-Sieira et al., 2010a).

Finally, melatonin is mainly involved in fish in the timing of rhythmic events, but also in growth, endocrine function, and metabolism (Falcón et al., 2010). In rainbow trout, melatonin in vitro treatment in hypothalamic tissue activated glucosensing mechanisms and elicited a response in the expression of neuropeptides compatible with an enhancement of orexigenic potential (Conde-Sieira et al., 2012a). In contrast, in liver a clear down-regulation of glucosensing potential occurred in response to melatonin treatment (Conde-Sieira et al., 2012b). This differential tissue response to melatonin treatment might relate to the day-night differences in glucosensing capacity observed in liver of rainbow trout (Conde-Sieira et al., 2012b).

In summary, several hormones involved in the regulation of energy homeostasis are involved in the modulation of glucose and fatty acid sensing systems in fish. Despite most studies were carried out with glucosensing systems, few with fatty acid sensing systems and none with putative amino acid sensing systems, a preliminary conclusion can be obtained in a way that anorexigenic/anabolic hormones demonstrated to activate nutrient sensing systems whereas orexigenic/catabolic hormones inhibit them. There are differences in the direction and magnitude of the responses compared with the mammalian model, which among other reasons might relate to the high degree of hormone variants present in fish (as a result of their additional genome duplication), and/or to the clear difference in dietary habits between both models. 


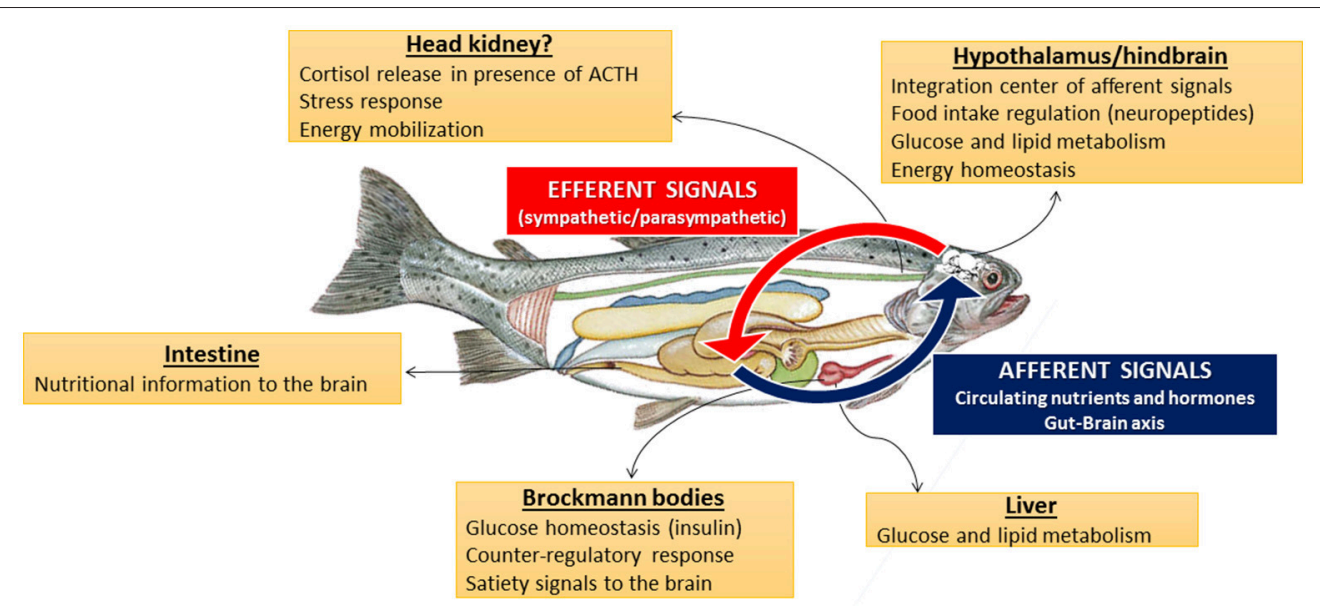

FIGURE 4 | Schematic drawing summarizing functions of nutrient sensing systems in central and peripheral tissues of fish.

\section{CONCLUSIONS}

Research carried out in recent years provided information for the presence and functioning of putative nutrient sensing systems either in peripheral or central areas of the few fish species assessed to date regarding this issue, mainly rainbow trout, as summarized in Figure 4.

The main role of these systems is to participate in the control of homeostasis through modulation of feeding behavior or other processes such as energy expenditure or hormone secretion. The known mechanisms are comparable to those of mammals in several aspects but clear differences arise in others, such as the fish capacity of detecting changes in circulating levels of MCFA or PUFA. These differences between fish and mammals might relate to at least three different reasons, among others. A first reason might relate to the large importance of amino acids for metabolic purposes in fish, not only in carnivorous but also in herbivorous and omnivorous species. A second reason may be due to the high variety of dietary fish habits resulting in large differences in gastrointestinal morphology and function. A third reason may rely on the existence in fish of multiple gene variants

\section{REFERENCES}

Aguilar, A. J., Conde-Sieira, M., López-Patiño, M. A., Míguez, J. M., and Soengas, J. L. (2011). In vitro leptin treatment of rainbow trout hypothalamus and hindbrain affects glucosensing and gene expression of neuropeptides involved in food intake regulation. Peptides 32, 232-240. doi: 10.1016/j.peptides.2010.11.007

Aguilar, A. J., Conde-Sieira, M., Polakof, S., Míguez, J. M., and Soengas, J. L. (2010). Central leptin treatment modulates brain glucosensing function and peripheral energy metabolism of rainbow trout. Peptides 31, 1044-1054. doi: 10.1016/j.peptides.2010.02.026

Agulleiro, M. J., Cortés, R., Fernández-Durán, B., Guillot, R., Navarro, S., Meimaridou, E., et al. (2013). Melanocortin 4 receptor becomes an ACTH receptor by coexpression of melanocortin receptor accessory protein 2. Mol. Endocrinol. 27, 1934-1945. doi: 10.1210/me. 2013-1099 in neuropeptides, hormones, and metabolic effectors resulting from the additional gene duplication of actinopterygians. The assessment of these topics, together with the possible presence and functioning of amino acid sensing systems in fish, as well as the elucidation of signaling pathways linking activity of sensors with the effectors controlling homeostasis, such as expression of neuropeptides controlling food intake, hormone secretion or metabolic changes, are open questions demanding further research in the near future.

\section{AUTHOR CONTRIBUTIONS}

Both authors designed the paper, wrote and approved the final version of the manuscript.

\section{FUNDING}

The authors acknowledge grants from Spanish Agencia Estatal de Investigación and European Fund for Regional Development (AGL2016-74857-C3-R and FEDER) to JS. MC was recipient of a postdoctoral fellowship from Xunta de Galicia.

Anthonisen, E. H., Berven, L., Holm, S., Nygård, M., Nebb, H. I., and Grønning-Wang, L. M. (2010). Nuclear receptor liver X receptor is O-GlcNAc-modified in response to glucose. J. Biol. Chem. 285, 1607-1615. doi: 10.1074/jbc.M109.082685

Archer, A., Laurencikiene, J., Ahmed, O., Steffensen, K. R., Parini, P., Gustafsson, J. A., et al. (2014). Skeletal muscle as a target of LXR agonist after long-term treatment: focus on lipid homeostasis. Am. J. Physiol. Endocrinol. Metab. 306, E494-E502. doi: 10.1152/ajpendo.00410.2013

Babaei, S., Sáez, A., Caballero-Solares, A., Fernández, F., Baanante, I. V., and Metón, I. (2017). Effect of dietary macronutrients on the expression of cholecystokinin, leptin, ghrelin and neuropeptide $\mathrm{Y}$ in gilthead sea bream (Sparus aurata). Gen. Comp. Endocrinol. 240, 121-128. doi: 10.1016/j.ygcen. 2016.10.003

Balasubramanian, M. N., Panserat, S., Dupont-Nivet, M., Quillet, E., Montfort, J., Le Cam, A., et al. (2016). Molecular pathways associated with the nutritional programming of plant-based diet acceptance in rainbow trout following 
an early feeding exposure. BMC Genomics 17:449. doi: 10.1186/s12864-0162804-1

Barma, P., Dey, D., Basu, D., Roy, S. S., and Bhattacharya, S. (2006). Nutritionally induced insulin resistance in an Indian perch: a possible model for type 2 diabetes. Curr. Sci. 90, 188-194.

Beall, C., Piipari, K., Al-Qassab, H., Smith, M. A., Parker, N., Carling, D., et al. (2010). Loss of AMP-activated protein kinase $\alpha 2$ subunit in mouse $\beta$-cells impairs glucose-stimulated insulin secretion and inhibits their sensitivity to hypoglycaemia. Biochem. J. 429, 323-333. doi: 10.1042/BJ20100231

Benoit, S. C., Kemp, C. J., Elias, C. F., Abplanalp, W., Herman, J. P., Migrenne, S., et al. (2009). Palmitic acid mediates hypothalamic insulin resistance by altering PKC-O subcellular localization in rodents. J. Clin. Invest. 119, 2577-2589. doi: $10.1172 /$ JCI36714

Berthoud, H. R. (2002). Multiple neural systems controlling food intake and body weight. Neurosci. Biobehav. Rev. 26, 393-428. doi: 10.1016/S01497634(02)00014-3

Berthoud, H. R., and Morrison, C. (2008). The brain, appetite, and obesity. Annu. Rev. Psychol. 59, 55-92. doi: 10.1146/annurev.psych.59.103006.093551

Betancor, M. B., Howarth, F. J., Glencross, B. D., and Tocher, D. R. (2014). Influence of dietary docosahexanoic acid in combination with other long-chain polyunsaturated fatty acids on expression of biosynthesis genes and phospholipid fatty acid compositions in tissues of post-smolt Atlantic salmon (Salmo salar). Comp. Biochem. Physiol. B. 172, 74-89. doi: 10.1016/j.cbpb.2014.04.007

Blouet, C., and Schwartz, G. J. (2010). Hypothalamic nutrient sensing in the control of energy homeostasis. Behav. Brain Res. 209, 1-12. doi: 10.1016/j.bbr.2009.12.024

Blouet, C., and Schwartz, G. J. (2012). Brainstem nutrient sensing in the nucleus of the solitary tract inhibits feeding. Cell Metab. 16, 579-587. doi: 10.1016/j.cmet.2012.10.003

Bonacic, K., Campoverde, C., Gómez-Arbones, J., Gisbert, E., Estevez, A., and Morais, S. (2016). Dietary fatty acid composition affects food intake and gut-brain satiety signaling in Senegalese sole (Solea senegalensis, Kaup 1858) larvae and post-larvae. Gen. Comp. Endocrinol. 228, 79-94. doi: 10.1016/j.ygcen.2016.02.002

Borges, P., Medale, F., Dias, J., and Valente, L. M. (2013). Protein utilisation and intermediary metabolism of Senegalese sole (Solea senegalensis) as a function of protein:lipid ratio. Br. J. Nutr. 109, 1373-1381. doi: 10.1017/S0007114512003418

Borges, P., Valente, L. M., Veron, V., Dias, K., Panserat, S., and Medale, F. (2014). High dietary lipid level is associated with persistent hyperglycaemia and downregulation of muscle Akt-mTOR pathway in Senegalese sole (Solea senegalensis). PLoS ONE 9:e102196. doi: 10.1371/journal.pone.0102196

Burnstock, G. (1959). The innervation of the gut of the brown trout (Salmo trutta). Quart. J. Microsc. Sci. 100, 199-219.

Capilla, E., Médale, F., Navarro, I., Panserat, S., Vachot, C., Kaushik, S., et al. (2003). Muscle insulin binding and plasma levels in relation to liver glucokinase activity, glucose metabolism and dietary carbohydrates in rainbow trout. Reg. Peptides 110, 123-132. doi: 10.1016/S0167-0115(02)00212-4

Caruso, M. A., Kittilson, J. D., Raine, J., and Sheridan, M. A. (2008). Rainbow trout (Oncorhynchus mykiss) possess two insulin-encoding mRNAs that are differentially expressed. Gen. Comp. Endocrinol. 155, 695-704. doi: 10.1016/j.ygcen.2007.09.006

Caruso, M. A., and Sheridan, M. A. (2011). New insights into the signaling system and function of insulin in fish. Gen. Comp. Endocrinol. 173, 227-247. doi: 10.1016/j.ygcen.2011.06.014

Castillo, J., Crespo, D., Capilla, E., Díaz, M., Chauvigné, F., Cerda, J., et al. (2009). Evolutionary structural and functional conservation of an ortholog of the GLUT2 glucose transporter gene (SLC2A2) in zebrafish. Am. J. Physiol. Regul. Integr. Comp. Physiol. 297, R1570-R1581. doi: 10.1152/ajpregu.00430.2009

Castro, C., Corraze, G., Firmino-Diógenes, A., Larroquet, L., Panserat, S., and Oliva-Teles, A. (2016). Regulation of glucose and lipid metabolism by dietary carbohydrate levels and lipid sources in gilthead sea bream juveniles. Br. J. Nutr. 116, 19-34. doi: 10.1017/S000711451600163X

Castro, C., Corraze, G., Pérez-Jimenez, A., Larroquet, L., Cluzeaud, M., Panserat, S., et al. (2015). Dietary carbohydrate and lipid source affect cholesterol metabolism of European sea bass (Dicentrarchus labrax) juveniles. Br. J. Nutr. 114, 1143-1156. doi: 10.1017/S0007114515002731
Cerdá-Reverter, J. M., and Canosa, L. F. (2009). "Neuroendocrine systems of the fish brain," in Fish Neuroendocrinology, eds N. J. Bernier, G. J. Van der Kraak, A. P. Farrell, and C. J. Brauner (Amsterdam: Elsevier), 3-74.

Cerdá-Reverter, J. M., and Peter, R. E. (2003). Endogenous melanocortin antagonist in fish: structure, brain mapping, and regulation by fasting of the goldfish agouti-related protein gene. Endocrinology 144, 3552-4561. doi: 10.1210/en.2003-0453

Chan, O., and Sherwin, R. S. (2012). Hypothalamic regulation of glucosestimulated insulin secretion. Diabetes 61, 564-565. doi: 10.2337/db11-1846

Chen, H., Huang, H., Chen, X., Deng, S., Zhu, C., Huang, H., et al. (2016). Structural and functional characterization of neuromedin $S$ in the teleost fish, zebrafish (Danio rerio). Comp. Biochem. Physiol. B. 191, 76-83. doi: 10.1016/j.cbpb.2015.09.007

Cheng, A.-C., Chen, C.-Y., Liou, C.-H., and Chang, C.-F. (2006). Effects of dietary protein and lipids on blood parameters and superoxide anion production in the grouper, epinephelus coioides (Serranidae: Epinephelinae). Zool. Stud. 45, 492-502.

Chisada, S., Kurokawa, T., Murashita, K., Rønnestad, I., Taniguchi, Y., Toyoda, A., et al. (2014). Leptin receptor-deficient (knockout) medaka, Oryzias latipes, show chronical up-regulated levels of orexigenic neuropeptides, elevated food intake and stage specific effects on growth and fat allocation. Gen. Comp. Endocrinol. 195, 9-20. doi: 10.1016/j.ygcen.2013.10.008

Conde-Sieira, M., Aguilar, A. J., López-Patiño, M. A., Míguez, J. M., and Soengas, J. L. (2010a). Stress alters food intake and glucosensing response in hypothalamus, hindbrain, liver, and Brockmann bodies of rainbow trout. Physiol. Behav. 101, 483-493. doi: 10.1016/j.physbeh.2010.07.016

Conde-Sieira, M., Agulleiro, M. J., Aguilar, A. J., Míguez, J. M., Cerdá-Reverter, J. M., and Soengas, J. L. (2010b). Effect of different glycaemic conditions on gene expression of neuropeptides involved in control of food intake in rainbow trout; interaction with stress. J. Exp. Biol. 213, 3858-3865. doi: 10.1242/jeb.048439

Conde-Sieira, M., Alvarez, R., López Patiño, M. A., Míguez, J. M., Flik, G., and Soengas, J. L. (2013). ACTH-stimulated cortisol release from head kidney of rainbow trout is modulated by glucose concentration. J. Exp. Biol. 216, 554-567. doi: 10.1242/jeb.076505

Conde-Sieira, M., Bonacic, K., Velasco, C., Valente, L. M., Morais, S., and Soengas, J. L. (2015a). Hypothalamic fatty acid sensing in Senegalese sole (Solea senegalensis): response to long-chain saturated, monounsaturated, and polyunsaturated (n-3) fatty acids. Am. J. Physiol. Regul. Integr. Comp. Physiol. 309, R1521-R1531. doi: 10.1152/ajpregu.00386.2015

Conde-Sieira, M., Librán-Pérez, M., López Patiño, M. A., Míguez, J. M., and Soengas, J. L. (2011). CRF treatment indices a readjustment in glucosensing capacity in the hypothalamus and hindbrain of rainbow trout. J. Exp. Biol. 214, 3887-3894. doi: 10.1242/jeb.061564

Conde-Sieira, M., Librán-Pérez, M., López Patiño, M. A., Soengas, J. L., and Míguez, J. M. (2012a). Melatonin treatment alters glucosensing capacity and mRNA expression levels of peptides related to food intake control in rainbow trout hypothalamus. Gen. Comp. Endocrinol. 178, 131-138. doi: 10.1016/j.ygcen.2012.04.011

Conde-Sieira, M., López-Patiño, M. A., Míguez, J. M., and Soengas, J. L. (2012b). Glucosensing capacity in rainbow trout liver displays day-night variations possibly related to melatonin action. J. Exp. Biol. 215, 3112-3119. doi: 10.1242/jeb.069740

Conde-Sieira, M., Salas-Leiton, E., Duarte, M. M., Pelusio, N. F., Soengas, J. L., and Valente, L. M. P. (2016). Short- and long-term metabolic responses to diets with different protein: carbohydrate ratio in Senegalese sole (Solea senegalensis, Kaup 1858). Br. J. Nutr. 115, 1896-1910. doi: 10.1017/S0007114516001057

Conde-Sieira, M., Soengas, J. L., and Valente, L. M. P. (2015b). Potential capacity of Senegalese sole (Solea senegalensis) to use carbohydrates: metabolic responses to hypo- and hyper-glycaemia. Aquaculture 438, 59-67. doi: 10.1016/j.aquaculture.2014.12.042

Craig, P. M., Massarsky, A., and Moon, T. W. (2013). Understanding glucose uptake during methionine deprivation in incubated rainbow trout (Oncorhynchus mykiss) hepatocytes using a non-radioactive method. Comp. Biochem. Physiol. B. 166, 23-29. doi: 10.1016/j.cbpb.2013.06.005

Cruciani-Guglielmacci, C., Hervalet, A., Douared, L., Sanders, N. M., Levin, B. E., Ktorza, A., et al. (2004). Beta oxidation in the brain is required for the effects of non-esterified fatty acids on glucose-induced insulin secretion in rats. Diabetologia 47, 2032-2038. doi: 10.1007/s00125-004-1569-2 
Cruz-García, L., Minghetti, M., Navarro, I., and Tocher, D. R. (2009). Molecular cloning, tissue expression and regulation of liver X Receptor (LXR) transcription factors of Atlantic salmon (Salmo salar) and rainbow trout (Oncorhynchus mykiss). Comp. Biochem. Physiol. B. 153, 81-88. doi: 10.1016/j.cbpb.2009.02.001

Davis, D. A., Lazo, J. P., and Arnold, C. R. (1999). Response of juvenile red drum (Sciaenops ocellatus) to practical diets supplemented with medium chain triglycerides. Fish Physiol. Biochem. 21, 235-247. doi: 10.1023/A:10 07836612376

de Pedro, N., Martínez-Álvarez, R., and Delgado, M. J. (2006). Acute and chronic leptin reduces food intake and body weight in goldfish (Carassius auratus). J. Endocrinol. 188, 513-520. doi: 10.1677/joe.1.06349

Diano, S., and Horvath, K. (2012). Mitochondrial uncoupling protein 2 (UCP2) in glucose and lipid metabolimsm. Trends Molec. Med. 18, 52-58. doi: 10.1016/j.molmed.2011.08.003

Dias, J., Rueda-Jasso, R., Panserat, S., da Conceicao, L. E. C., Gomes, E. F., and Dinis, M. T. (2004). Effect of dietary carbohydrate-to-lipid ratios on growth, lipid deposition and metabolic hepatic enzymes in juvenile Senegalese sole (Solea senegalensis, Kaup). Aquacult. Res. 35, 1122-1130. doi: 10.1111/j.1365-2109.2004.01135.x

Diéguez, C., Frühbeck, G., and López, M. (2009). Hypothalamic lipids and the regulation of energy homeostasis. Obes. Fact. 2, 126-135. doi: $10.1159 / 000209251$

Diéguez, C., Vazquez, M. J., Romero, A., López, M., and Nogueiras, R. (2011). Hypothalamic control of lipid metabolism: focus on leptin, ghrelin and melanocortins. Neuroendocrinology 94, 1-11. doi: 10.1159/000328122

Díez-Sampedro, A., Hirayama, B. A., Osswald, C., Gorboulev, V., Baumgarten, K., Volk, C., et al. (2003). A glucose sensor hiding in a family of transporters. Proc. Natl. Acad. Sci. U.S.A. 100, 11753-11758. doi: 10.1073/pnas.1733027100

Donovan, C. M., and Watts, A. G. (2014). Peripheral and central glucose sensing in hypoglycemic detection. Physiology 29, 314-324. doi: 10.1152 /physiol.00069.2013

Duca, F. A., and Yue, J. T. (2014). Fatty acid sensing in the gut and the hypothalamus: in vivo and in vitro perspectives. Mol. Cell Endocrinol. 397, 23-33. doi: 10.1016/j.mce.2014.09.022

Efeyan, A., Comb, W. C., and Sabatini, D. M. (2015). Nutrient sensing mechanisms and pathways. Nature 517, 302-310. doi: 10.1038/nature14190

Ekberg, J. H., Hauge, M., Kristensen, L. V., Madsen, A. N., Engelstoft, M. S., Husted, A.-S., et al. (2016). GPR119, a major enteroendocrine sensor of dietary triglyceride metabolites co acting in synergy with FFAl (GPR40). Endocrinology 157, 4561-4569. doi: 10.1210/en.2016-1334

Enes, P., Panserat, S., Kaushik, S., and Oliva-Teles, A. (2006). Effect of normal and waxy maize starch on growth, food utilization and hepatic glucose metabolism in European sea bass (Dicentrarchus labrax) juveniles. Comp. Biochem. Physiol. B 143, 89-96. doi: 10.1016/j.cbpa.2005.10.027

Enes, P., Panserat, S., Kaushik, S., and Oliva-Teles, A. (2009). Nutritional regulation of hepatic glucose metabolism in fish. Fish Physiol. Biochem. 35, 519-539. doi: 10.1007/s10695-008-9259-5

Epple, A., Brinn, J. E., Burggren, W., Ishii, S., Langer, H., Neuweiler, G., et al. (1987). The Comparative Physiology of the Pancreatic Islets. Berlin: SpringerVerlag.

Evans, M. L., McCrimmon, R. J., Flanagan, D. E., Keshavarz, T., Fan, X., McNay, E. C., et al. (2004). Hypothalamic ATP-sensitive $\mathrm{K}^{+}$channels play a key role in sensing hypoglycemia and triggering counterregulatory epinephrine and glucagon responses. Diabetes 53, 2542-2551. doi: 10.2337/diabetes.53. 10.2542

Falcón, J., Migaud, H., Muñoz-Cueto, J. A., and Carrillo, M. (2010). Current knowledge on the melatonin system in teleost fish Gen. Comp. Endocrinol. 165, 469-482. doi: 10.1016/j.ygcen.2009.04.026

Figueiredo-Silva, A., Corraze, G., Borges, P., and Valente, L. (2010). Dietary protein/lipid level and protein source effects on growth, tissue composition and lipid metabolism of blackspot seabream (Pagellus bogaraveo). Aquacult. Nutr. 16, 173-187. doi: 10.1111/j.1365-2095.2009.00649.x

Figueiredo-Silva, A. C., Kaushik, S., Terrier, F., Schrama, J. W., Médale, F., and Geurden, I. (2012a). Link between lipid metabolism and voluntary food intake in rainbow trout fed coconut oil rich in medium-chain TAG. Br. J. Nutr. 107, 1714-1725. doi: $10.1017 /$ S0007114511004739
Figueiredo-Silva, A. C., Panserat, S., Kaushik, S., Geurden, I., and Polakof, S (2012b). High levels of dietary fat impair glucose homeostasis in rainbow trout. J. Exp. Biol. 215, 169-178. doi: 10.1242/jeb.063933

Figueiredo-Silva, A. C., Saravanan, S., Schrama, J. W., Kaushik, S., and Geurden, I. (2012c). Macronutrient-induced differences in food intake relate with hepatic oxidative metabolism and hypothalamic regulatory neuropeptides in rainbow trout (Oncorhynchus mykiss). Physiol. Behav. 106, 499-505. doi: 10.1016/j.physbeh.2012.03.027

Figueiredo-Silva, A. C., Saravanan, S., Schrama, J. W., Panserat, S., Kaushik, S., and Geurden, I. (2013). A comparative study of the metabolic response in rainbow trout and Nile tilapia to changes in dietary macronutrient composition. $\mathrm{Br}$. J. Nutr. 109, 816-826. doi: 10.1017/S000711451200205X

Fioramonti, X., Contié, S., Song, Z., Routh, V. H., Lorsignol, A., and Pénicaud, L. (2007). Characterization of glucosensing neuron subpopulations in the arcuate nucleus. Integration in neuropeptide $\mathrm{Y}$ and pro-opio melanocortin networs? Diabetes 56, 1219-1227. doi: 10.2337/db06-0567

Fioramonti, X., Lorsignol, A., Taupignon, A., and Pénicaud, L. (2004). A new ATP-sensitive $\mathrm{K}^{+}$channel-independent mechanism is involved in glucose-excited neurons of mouse arcuate nucleus. Diabetes 53, 2767-2775. doi: $10.2337 /$ diabetes.53.11.2767

Forsman, A., and Ruohonen, K. (2009). Dynamics of protein and lipid intake regulation of rainbow trout studied with a wide lipid range of encapsulated diets and self-feeders. Physiol. Behav. 96, 85-90. doi: 10.1016/j.physbeh.2008.08.018

Fromentin, G., Darcel, N., Chaumontet, C., Marsset-Baglieri, A., Nadkarni, N., and Tomé, D. (2012). Peripheral and central mechanisms involved in the control of food intake by dietary amino acids and proteins. Nutr. Res. Rev. 25, 29-39. doi: $10.1017 /$ S0954422411000175

Gao, S., and Lane, D. (2003). Effect of the anorectic fatty acid synthase inhibitor C75 on neuronal activity in the hypothalamus and brainstem. Proc. Natl. Acad. Sci. U.S.A. 100, 5628-5633. doi: 10.1073/pnas. 1031698100

Gao, S., Moran, T. H., Lopaschuk, G. D., and Butler, A. A. (2013). Hypothalamic malonyl-CoA and the control of food intake. Physiol. Behav. 122, 17-24. doi: 10.1016/j.physbeh.2013.07.014

Gélineau, A., and Boujard, T. (2001). Oral administration of cholecystokinin receptor antagonists increase feed intake in rainbow trout. J. Fish Biol. 58, 716-724. doi: 10.1111/j.1095-8649.2001.tb00524.x

Gélineau, A., Corraze, G., Boujard, T., Larroquet, L., and Kaushik, S. (2001). Relation between dietary lipid level and voluntary feed intake, growth, nutrient gain, lipid deposition and hepatic lipogenesis in rainbow trout. Reprod. Nutr. Dev. 41, 487-503. doi: 10.1051/rnd:2001103

Gesto, M., Otero-Rodiño, C., López-Patiño, M. A., Míguez, J. M., Soengas, J. L., and Conde-Sieira, M. (2014). Is plasma cortisol response to stress in rainbow trout regulated by catecholamine-induced hyperglycemia? Gen. Comp. Endocrinol. 205, 207-217. doi: 10.1016/j.ygcen.2014.04.002

Geurden, I., Aramendi, M., Zambonino-Infante, J., and Panserat, S. (2007). Early feeding of carnivorous rainbow trout (Oncorhynchus mykiss) with a hyperglucidic diet during a short period: effect on dietary glucose utilization in juveniles. Am. J. Physiol. Regul. Integr. Comp. Physiol. 292, R2275-R2283. doi: 10.1152/ajpregu.00444.2006

Gomes, A. S., Jordal, A. E., Olsen, K., Harboe, T., Power, D. M., and Rønnestad, I. (2015). Neuroendocrine control of appetite in Atlantic halibut (Hippoglossus hippoglossus): changes during metamorphosis and effects of feeding. Comp. Biochem. Physiol. A. 183, 116-125. doi: 10.1016/j.cbpa.2015.01.009

Gomez-Pinilla, F., and Ying, Z. (2010). Differential effects of exercise and dietary docosahexanoic acid on molecular systems associated with control of allostasis in the hypothalamus and hippocampus. Neuroscience 168, 130-137. doi: 10.1016/j.neuroscience.2010.02.070

Gong, G., Xue, M., Wang, J., Wu, X.-F., Zheng, Y.-H., Han, F., et al. (2014). The regulation of gluconeogenesis in the Siberian sturgeon (Acipenser baerii) affected later in life by a short-term high-glucose programming during early life. Aquaculture 436, 127-136. doi: 10.1016/j.aquaculture.2014.10.044

Gong, N., and Björnsson, B. T. (2014). Leptin signaling in the rainbow trout central nervous system is modulated by a truncated leptin receptor isoform. Endocrinology 155, 2445-2455. doi: 10.1210/en.2013-2131

Gong, N., Johansson, M., and Björnsson, B. T. (2016b). Impaired central leptin signaling and sensitivity in rainbow trout with high muscle adiposity. Gen. Comp. Endocrinol. 235, 48-56. doi: 10.1016/j.ygcen.2016.06.013 
Gong, N., Jönsson, E., and Björnsson, B. T. (2016a). Acute anorexigenic action of leptin in rainbow trout is mediated by the hypothalamic Pi3k pathway. J. Mol. Endocrinol. 56, 227-238. doi: 10.1530/JME-15-0279

González, J. A., Reimann, F., and Burdakov, D. (2009). Dissociation between sensing and metabolism of glucose in sugar sensing neurones. J. Physiol. 587, 41-48. doi: 10.1113/jphysiol.2008.163410

Greco, J. A., Oosterman, J. E., and Belsham, D. D. (2014). Differential effects of omega-3 fatty acid docosahexanoic acid and palmitate on the circadian transcriptional profile of clock genes in immortalized hypothalamic neurons. Am. J. Physiol. Regul. Integr. Comp. Physiol. 307, R1049-R1060. doi: 10.1152/ajpregu.00100.2014

Gutiérrez, J., and Plisetskaya, E. M. (1994). "Peptide receptor assay: insulin receptors," in Biochemistry and Molecular Biology of Fishes, Vol 3, eds P. W. Hochachka and T. P. Mommsen (Amsterdam: Elsevier), 429-444.

Hasebe, M., Kanda, S., and Oka, Y. (2016). Female-specific glucose sensitivity of GhRH1 neurons leads to sexually dimorphic inhibition of reproduction in medaka. Endocrinology 157, 4318-4329. doi: 10.1210/en. 2016-1352

Hashiguchi, Y., Furuta, Y., Kawahara, R., and Nishida, M. (2007). Diversification and adaptive evolution of putative sweet taste receptors in threespine stickleback. Gene 396, 170-179. doi: 10.1016/j.gene.2007.03.015

He, A. Y., Ning, L. J., Chen, L. Q., Chen, Y. L., Xing, Q., Li, J. M., et al. (2015). Systemic adaptation of lipid metabolism in response to low- and high-fat diet in Nile tilapia (Oreochromis niloticus). Physiol. Rep. 3:e12485. doi: $10.14814 /$ phy2.12485

Heeley, N., and Blouet, C. (2016). Central amino acid sensing in the control of feeding behavior. Front. Endocrinol. 7:148. doi: 10.3389/fendo.2016.00148

Hemre, G. I., Mommsen, T. P., and Krogdahl, Å. (2002). Carbohydrates in fish nutrition: effects on growth, glucose metabolism and hepatic enzymes. Aquacult. Nutr. 8, 175-194. doi: 10.1046/j.1365-2095.2002.00200.x

Hemre, G. I., and Sandnes, K. (1999). Effect of dietary lipid level on muscle composition in Atlantic salmon Salmo salar. Aquacult. Nutr. 5, 9-16. doi: 10.1046/j.1365-2095.1999.00081.x

Herrera Moro Chao, D., Argmann, C., Van Eijk, M., Boot, R. G., Ottenhoff, R., Van Roomen, C., et al. (2016). Impact of obesity on taste receptor expression in extra-oral tissues: emphasis on hypothalamus and brainstem. Sci. Rep. 6:29094. doi: 10.1038/srep29094

Hevrøy, E. M., Waagbø, R., Torstensen, B. E., Takle, H., Stubhaug, I., Jørgensen, S. M., et al. (2012). Ghrelin is involved in voluntary anorexia in Atlantic salmon raised at elevated sea temperatures. Gen. Comp. Endocrinol. 175, 118-134. doi: 10.1016/j.ygcen.2011.10.007

Himick, B. A., and Peter, R. E. (1994). CCK/gastrin-like immunoreactivity in brain and gut, and CCK suppression of feeding in goldfish. Am. J. Physiol. Regul. Integr. Comp. Physiol. 267, R841-R851.

Hoskins, L. J., and Volkoff, H. (2012). The comparative endocrinology of feeding in fish: insights and challenges. Gen. Comp. Endocrinol. 176, 327-335. doi: 10.1016/j.ygcen.2011.12.025

Hrytsenko, O., Wright, J. R. Jr., and Pohajdak, B. (2008). Regulation of insulin gene expression and insulin production in Nile tilapia (Oreochromis niloticus). Gen. Comp. Endocrinol. 155, 328-340. doi: 10.1016/j.ygcen.2007.05.006

Hu, Z., Cha, S. H., Chohnan, S., and Lane, M. D. (2011). Hypothalamic malonylCoA as a mediator of feeding behavior. Proc. Natl. Acad. Sci. U.S.A. 100, 12624-12629. doi: 10.1073/pnas. 1834402100

Hutchins, C. G., Rawles, S. D., and Gatlin, D. M. (1998). Effects of dietary carbohydrate kind and level on growth, body composition and glycemic response of juvenile sunshine bass (Morone chrysops female $\mathrm{x}$ Morone saxatilis male). Aquaculture 161, 187-199. doi: 10.1016/S0044-8486(97) 00269-X

Ishimaru, Y., Okada, S., Naito, H., Nagai, T., Yasuoka, A., Matsumoto, I., et al. (2005). Two families of candidate taste receptors in fishes. Mech. Dev. 122, 1310-1321. doi: 10.1016/j.mod.2005.07.005

Jin, J., Panserat, S., Kamalam, B. S., Aguirre, P., Véron, V., and Médale, F. (2014). Insulin regulates lipid and glucose metabolism similarly in two lines of rainbow trout divergently selected for muscle fat content. Gen. Comp. Endocrinol. 204, 49-59. doi: 10.1016/j.ygcen.2014.04.027

Johansen, S. J. S., Ekli, M., and Jobling, M. (2002). Is there lipostatic regulation of feed intake in Atlantic salmon Salmo salar L.? Aquacult. Res. 33, 515-524. doi: 10.1046/j.1365-2109.2002.00736.x
Johansen, S. J. S., Sveier, H., and Jobling, M. (2003). Lipostatic regulation of feed intake in Atlantic salmon Salmo salar L. defending adiposity at the expense of growth? Aquacult. Res. 34, 317-331. doi: 10.1046/j.1365-2109.2003.00821.x

Jönsson, E., Forsman, A., Einarsdottir, I. E., Egnér, B., Ruohonen, K., and Björnsson, B. T. (2006). Circulating levels of cholecystokinin and gastrinreleasing peptide in rainbow trout fed different diets. Gen. Comp. Endocrinol. 148, 187-194. doi: 10.1016/j.ygcen.2006.02.016

Jönsson, E., Kaiya, H., and Björnsson, B. T. (2010). Ghrelin decreases food intake in juvenile rainbow trout (Oncorhynchus mykiss) through the central anorexigenic corticotropin-releasing factor system. Gen. Comp. Endocrinol. 166, 39-46. doi: 10.1016/j.ygcen.2009.11.001

Jurczyk, A., Roy, N., Bajwa, R., Gut, P., Lipson, K., Yang, C., et al. (2011). Dynamic glucoregulation and mammalian-like responses to metabolic and developmental disruption in zebrafish. Gen. Comp. Endocrinol. 170, 334-345. doi: 10.1016/j.ygcen.2010.10.010

Kamalam, B. S., Médale, F., Larroquet, L., Corraze, G., and Panserat, S. (2013). Metabolism and fatty acid profile in fat and lean rainbow trout lines fed with vegetable oil: effect of carbohydrates. PLOS ONE 8:e76570. doi: 10.1371/journal.pone.0076570

Kang, K. S., Yahashi, S., Azuma, M., and Matsuda, K. (2010). The anorexigenic effect of cholecystokinin octapeptide in a goldfish model is mediated by the vagal afferent and subsequently through the melanocortin- and corticotropin-releasing hormone-signaling pathways. Peptides 31, 2130-2134. doi: 10.1016/j.peptides.2010.07.019

Kaushik, S., Médale, F., Fauconneau, B., and Blanc, D. (1989). Effect of digestible carbohydrates on protein - energy utilization and on glucose metabolism in rainbow trout (Salmo gairdneri R). Aquaculture 79, 63-74. doi: 10.1016/0044-8486(89)90446-8

Keane, K., and Newsholme, P. (2014). Metabolic regulation of insulin secretion. Vitam. Horm. 95, 1-33. doi: 10.1016/B978-0-12-800174-5.00001-6

Kehoe, A. S., and Volkoff, H. (2007). Cloning and charac-terization of neuropeptide $\mathrm{Y}$ (NPY) and cocaine and amphetamine regulated transcript (CART) in Atlantic cod (Gadus morhua). Comp. Biochem. Physiol. A. 146, 451-461. doi: 10.1016/j.cbpa.2006.12.026

Kirchner, S., Panserat, S., Lim, P. L., Kaushik, S., and Ferraris, R. P. (2008). The role of hepatic, renal and intestinal gluconeogenic enzymes in glucose homeostasis of juvenile rainbow trout. J. Comp. Physiol. B. 178, 429-438. doi: 10.1007/s00360-007-0235-7

Kling, P., Rønnestad, I., Stefansson, S. O., Murashita, K., Kurokawa, T., and Björnsson, B. T. (2009). A homologous salmonid leptin radioimmunoassay indicates elevated plasma leptin levels during fasting of rainbow trout. Gen. Comp. Endocrinol. 162, 307-312. doi: 10.1016/j.ygcen.2009.04.003

Kobayashi, Y., Peterson, B. C., and Waldbieser, G. C. (2008). Association of cocaine- and amplhetamine-regulated transcript (CART) messenger RNA level, food intake, and growth in channel catfish. Comp. Biochem. Physiol. A. 151, 219-225. doi: 10.1016/j.cbpa.2008.06.029

Kokrashvili, Z., Mosinger, B., and Margolskee, R. F. (2009). Taste signaling elements expressed in gut enteroendocrine cells regulate nutrientresponsive secretion of gut hormones. Am. J. Clin. Nutr. 90, 822S-825S. doi: 10.3945/ajcn.2009.27462t

Kolditz, C., Borthaire, M., Richard, N., Corraze, G., Panserat, S., Vachot, C., et al. (2008). Liver and muscle metabolic changes induced by dietary energy content and genetic selection in rainbow trout (Oncorhynchus mykiss). Am. J. Physiol. Regul. Integr. Comp. Physiol. 294, R1154-R1164. doi: 10.1152/ajpregu.00766.2007

Krogdahl, A., Sundby, A., and Olli, J. J. (2004). Atlantic salmon (Salmo salar) and rainbow trout (Oncorhynchus mykiss) digest and metabolize nutrients differently. Effects of water salinity and dietary starch level. Aquaculture 229, 335-360. doi: 10.1016/S0044-8486(03)00396-X

Kyriazis, G. A., Smith, K. R., Tyrberg, B., Hussain, T., and Pratley, R. E. (2014). Sweet taste receptors regulate basal insulin secretion and contribute to compensatory insulin hypersecretion during the development of diabetes in male mice. Endocrinology 155, 2112-2121. doi: 10.1210/en. 2013-2015

Lansard, M., Panserat, S., Plagnes-Juan, E., Seiliez, I., and Skiba-Cassy, S. (2010). Integration of insulin and amino acid signals that regulate hepatic metabolismrelated gene expression in rainbow trout: role of TOR. Amino Acids 39, 801-810. doi: 10.1007/s00726-010-0533-3 
Lansard, M., Panserat, S., Seiliez, I., Polakof, S., Plagnes-Juan, E., Geurden, I., et al. (2009). Hepatic protein kinase B (Akt)-target of rapamycin (TOR)-signalling pathways and intermediary metabolism in rainbow trout (Oncorhynchus mykiss) are not significantly affected by feeding plant-based diets. Br. J. Nutr. 102, 1564-1573. doi: 10.1017/S000711450999095X

Le Foll, C., Irani, B. G., Magnan, C., Dunn-Meynell, A. A., and Levin, B. E. (2009). Characteristics and mechanisms of hypothalamic neuronal fatty acid sensing. Am. J. Physiol. Regul. Integr. Comp. Physiol. 297, R655-R664. doi: 10.1152/ajpregu.00223.2009

Leibush, B., Parrizas, I., Navarro, I., Lappova, M. A., Maestro, M., Encinas, M., et al. (1996). Insulin and insulin-like growth factor-I receptors in fish brain. Regul. Peptides 61, 155-161. doi: 10.1016/0167-0115(95)00154-9

Levin, B. E. (2006). Metabolic sensing neurons and the control of energy homeostasis. Physiol. Behav. 89, 486-489. doi: 10.1016/j.physbeh.2006.07.003

Levin, B. E., Routh, V. H., Kang, L., Sanders, N. M., and Dunn-Meynell, A. A. (2004). Neuronal glucosensing. What do we know after 50 years? Diabetes 53 , 2521-2528. doi: 10.2337/diabetes.53.10.2521

Li, A., Yuan, X., Liang, X.-F., Liu, L., Li, J., Li, B., et al. (2016). Adaptations of lipid metabolism and food intake in response to low and high fat diets in juvenile grass carp (Ctenopharyngodon idellus). Aquaculture 457, 43-49. doi: 10.1016/j.aquaculture.2016.01.014

Li, G. G., Liang, X. F., Xie, Q., Li, G., Yu, Y., and Lai, K. (2010). Gene structure, recombinant expression and functional characterization of grass carp leptin. Gen. Comp. Endocrinol. 166, 117-127. doi: 10.1016/j.ygcen.2009.10.009

Liang, H., Ren, M., Habte-Tsion, H.-M., Ge, X., Xie, J., Mi, H., et al. (2016). Dietary arginine affects growth performance, plasma amino acid contents and gene expressions of the TOR signaling pathway in juvenile blunt snout bream, Megalobrama amblycephala. Aquaculture 461, 1-8. doi: 10.1016/j.aquaculture.2016.04.009

Liang, X. F., Ogata, H. Y., Oku, H., Chen, J., and Hwang, F. (2003). Abundant and constant expression of uncoupling protein 2 in the liver of red sea bream Pagrus major. Comp. Biochem. Physiol. A 136, 655-661. doi: 10.1016/S1095-6433(03)00218-6

Librán-Pérez, M., Figueiredo-Silva, A. C., Panserat, S., Geurden, I., Míguez, J. M., Polakof, S., et al. (2013b). Response of hepatic lipid and glucose metabolism to a mixture or single fatty acids: possible presenc of fatty acid-sensing mechanisms. Comp. Biochem. Physiol. A. 164, 241-248. doi: 10.1016/j.cbpa.2012.09.012

Librán-Pérez, M., Geurden, I., Dias, K., Corraze, G., Panserat, S., and Soengas, J. L. (2015b). Feeding rainbow trout with a lipid-enriched diet: effects on fatty acid sensing, regulation of food intake and cellular signaling pathways. J. Exp. Biol. 218, 2610-2619. doi: 10.1242/jeb.123802

Librán-Pérez, M., López-Patiño, M. A., Míguez, J. M., and Soengas, J. L. (2013a). Oleic acid and octanoic acid sensing capacity in rainbow trout Oncorhynchus mykiss is direct in hypothalamus and Brockmann bodies. PLoS ONE 8:e59507. doi: 10.1371/journal.pone.0059507

Librán-Pérez, M., López-Patiño, M. A., Míguez, J. M., and Soengas, J. L. (2013c). In vitro response of putative fatty acid-sensing systems in rainbow trout liver to increased levels of oleate or octanoate. Comp. Biochem. Physiol. A. 165, 288-294. doi: 10.1016/j.cbpa.2013.03.024

Librán-Pérez, M., Otero-Rodiño, C., López-Patiño, M. A., Míguez, J. M., and Soengas, J. L. (2014a). Central administration of oleate or octanoate activates hypothalamic fatty acid sensing and inhibits food intake in rainbow trout. Physiol. Behav. 129, 272-279. doi: 10.1016/j.physbeh.2014.02.061

Librán-Pérez, M., Otero-Rodiño, C., López-Patiño, M. A., Míguez, J. M., and Soengas, J. L. (2015c). Effects of intracerebroventricular treatment with oleate or octanoate on fatty acid metabolism in Brockmann bodies and liver of rainbow trout. Aquacult. Nutr. 21, 194-205. doi: 10.1111/anu.12158

Librán-Pérez, M., Polakof, S., López-Patiño, M. A., Míguez, J. M., and Soengas, J. L. (2012). Evidence of a metabolic fatty-acid sensing system in the hypothalamus and Brockmann bodies of rainbow trout: implications in food intake regulation. Am. J. Physiol. Regul. Integr. Comp. Physiol. 302, R1340-R1350. doi: 10.1152/ajpregu.00070.2012

Librán-Pérez, M., Velasco, C., López-Patiño, M. A., Míguez, J. M., and Soengas, J. L. (2014b). Counter-regulatory response to a fall in circulating fatty acid levels in rainbow trout. Possible involvement of the hypothalamus-pituitaryinterrenal axis. PLoS ONE 9:e113291. doi: 10.1371/journal.pone.0113291

Librán-Pérez, M., Velasco, C., Otero-Rodiño, C., López-Patiño, M. A., Míguez, J. M., and Soengas, J. L. (2015a). Effects of insulin treatment on the response to oleate and octanoate of food intake and fatty acid-sensing systems in rainbow trout. Domestic Anim. Endocrinol. 53, 124-135. doi: 10.1016/j.domaniend.2015.06.004

Librán-Pérez, M., Velasco, C., Otero-Rodiño, C., López-Patiño, M. A., Míguez, J. M., and Soengas, J. L. (2015d). Metabolic response in liver and Brockmann bodies of rainbow trout to inhibition of lipolysis; possible involvement of the hypothalamus-pituitary-interrenal (HPI) axis. J. Comp. Physiol. B. 185, 413-423. doi: 10.1007/s00360-015-0894-8

Loftus, T. M., Jaworsky, D. E., Frehywot, G. J., Townsend, C. A., Ronnett, G. V., Lane, M. D., et al. (2000). Reduced food intake and body weight in mice treated with fatty acid synthase inhibitors. Science 288, 2379-2381. doi: $10.1126 /$ science.288.5475.2379

López, M., Lelliott, C. J., and Vidal-Puig, A. (2007). Hypothalamic fatty acid metabolism: a housekeeping pathway that regulates food intake. Bioessays 29 , 248-261. doi: 10.1002/bies.20539

López, M., Tovar, S., Vázquez, M. J., Nogueiras, R., Señarís, R., and Diéguez, C. (2005). Sensing the fat: fatty acid metabolism in the hypothalamus and the melanocortin system. Peptides 26, 1753-1758. doi: 10.1016/j.peptides. 2004.11.025

Luo, L., Xue, M., Vachot, C., Geurden, I., and Kaushik, S. (2014). Dietary medium chain fatty acids from coconut oil have little effects on postprandial plasma metabolite profiles in rainbow trout (Oncorhynchus mykiss). Aquaculture 420-421, 24-31. doi: 10.1016/j.aquaculture.2013.10.024

MacDonald, E., and Volkoff, H. (2009). Cloning, distribution and effects of season and nutritional status on the expression of neuropeptide Y (NPY), cocaine and amphetamine regulated transcript (CART) and cholecystokinin (CCK) in winter flounder (Pseudopleuronectes americanus). Horm. Behav. 56, 58-65. doi: 10.1016/j.yhbeh.2009.03.002

MacDonald, M. J., Dobrzyn, A., Ntambi, J., and Stoker, S. W. (2008). The role of rapid lipogenesis in insulin secretion: insulin secretagogues acutely alter lipid composition of INS-1 832/13 cells. Arch. Biochem. Biophys. 470, 153-162. doi: 10.1016/j.abb.2007.11.017

MacDonald, P. E., Joseph, J. W., and Rorsman, P. (2005). Glucose-sensing mechanisms in pancreatic beta-cells. Philos. Trans. R. Soc. Lond. B Biol. Sci. 360, 2211-2225. doi: 10.1098/rstb.2005.1762

Magnuson, M. A., and Matschinsky, F. M. (2004). "Glucokinase as a glucose sensor: past, present and future," in Glucokinase and Glycemic Disease: From Basics to Novel Therapeutics, eds F. M. Matschinsky and M. A. Magnuson (Basel: Karger), 1-17.

Martinez-Rubio, L., Wadsworth, S., González Vecino, J. L., Bell, J. G., and Tocher, D. R. (2013). Effect of dietary digestible energy content on expression of genes of lipid metabolism and LC-PUFA biosynthesis in liver of Atlantic salmon (Salmo salar L.). Aquaculture 384-387, 94-103. doi: 10.1016/j.aquaculture.2012.12.010

Marty, N., Dallaporta, M., Foretz, M., Emery, M., Tarussio, D., Bady, I., et al. (2005). Regulation of glucagon secretion by glucose transporter type 2 (GLUT2) and astrocyte-dependent glucose sensors. J. Clin. Invest. 115, 3545-3553. doi: 10.1172/JCI26309

Marty, N., Dallaporta, M., and Thorens, B. (2007). Brain glucose sensing, counteregulation, and energy homeostasis. Physiology 22, 241-251. doi: 10.1152/physiol.00010.2007

Maurin, A. C., Benani, A., Lorsignol, A., Brenachot, X., Parry, L., Carraro, V., et al. (2014). Hypothalamic elF2 $\alpha$ signaling regulates food intake. Cell Rep. 6 , 438-444. doi: 10.1016/j.celrep.2014.01.006

Mazur, C. N., Higgs, D. A., Plisetskaya, E., and March, B. E. (1992). Utilization of dietary starch and glucose tolerance in juvenile Chinook salmon (Oncorhynchus tshawytscha) of different strains in seawater. Fish Physiol. Biochem. 10, 303-313. doi: 10.1007/BF00004479

McCrimmon, R. J., Evans, M. L., Fan, X., McNay, E. C., Chan, O., Ding, Y., et al. (2005). Activation of ATP-sensitive $\mathrm{K}^{+}$channels in the ventromedial hypothalamus amplifies counterregulatory hormone responses to hypoglycemia in normal and recurrently hypoglycemic rats. Diabetes 54, 3169-3174. doi: 10.2337/diabetes.54.11.3169

McCrimmon, R. J., Song, Z., Cheng, H., McNay, E. C., Weickart-Yeckel, C., Routh, V. H., et al. (2006). Corticotrophin-releasing factor receptors within the ventromedial hypothalamus regulate hypoglycemia-induced hormonal counterregulation. J. Clin. Invest. 116, 1723-1730. doi: 10.1172/ JCI27775 
Michel, M., Page-McCaw, P. S., Chen, W., and Cone, R. D. (2016). Leptin signaling regulates glucose homeostasis, but not adipostasis, in the zebrafish. Proc. Natl. Acad. Sci. U.S.A. 113, 3084-3089. doi: 10.1073/pnas.1513 212113

Migrenne, S., Le Foll, C., Levin, B. E., and Magnan, C. (2011). Brain lipid sensing and nervous control of energy balance. Diabetes Metab. 37, 83-88. doi: 10.1016/j.diabet.2010.11.001

Migrenne, S., Magnan, C., and Cruciani-Guglielmacci, C. (2007). Fatty acid sensing and nervous control of energy homeostasis. Diabetes Metab. 33, 177-182. doi: 10.1016/j.diabet.2007.01.006

Migrenne, S., Marsolier, N., Cruciani-Guglielmacci, C., and Magnan, C. (2006). Importance of the gut-brain axis in the control of glucose homeostasis. Curr. Opin. Pharmacol. 6, 592-597. doi: 10.1016/j.coph.2006.08.004

Miguel-Aliaga, I. (2012). Nerveless and gutsy: intestinal nutrient sensing from invertebrates to humans. Sem. Cell Deve. Biol. 23, 614-620. doi: $10.1016 /$ j.semcdb.2012.01.002

Miki, T., Liss, B., Minami, K., Shiuchi, T., Saraya, A., Kashima, Y., et al. (2001). ATP-sensitive $\mathrm{K}^{+}$channels in the hypothalamus are essential for the maintenance of glucose homeostasis. Nat. Neurosci. 4, 507-512. doi: 10.1038/ 87455

Mitro, N., Mak, P. A., Vargas, L., Godio, C., Hampton, E., Molteni, V., et al. (2007). The nuclear receptor LXR is a glucose sensor. Nature 445, 219-223. doi: 10.1038/nature05449

Miura, T., Maruyama, K., Shimakura, S., Kaiya, H., Uchiyama, M., Kangawa, K., et al. (2006). Neuropeptide y mediates ghrelin-induced feeding in the goldfish, Carassius auratus. Neurosci. Lett. 407, 279-283. doi: 10.1016/j.neulet.2006.08.071

Mobbs, C. V., Isoda, F., Makimura, H., Mastaitis, J., Mizuno, T., Shu, I. W., et al. (2005). Impaired glucose signaling as a cause of obesity and the metabolic syndrome: the glucoadipostatic hypothesis. Physiol. Behav. 85, 2-23. doi: 10.1016/j.physbeh.2005.04.005

Mommsen, T. P., and Plisetskaya, E. M. (1991). Insulin in fishes and agnathans history structure and metabolic regulation. Rev. Aquat Sci. 4, 225-259.

Morash, A. J., Bureau, D. P., and McClelland, G. B. (2009). Effects of dietary fatty acid composition on the regulation of carnitine palmitoyltransferase (CPT) I in rainbow trout (Oncorhynchus mykiss). Comp. Biochem. Physiol. B. 152, 85-93. doi: 10.1016/j.cbpb.2008.10.005

Morgan, K., Obici, S., and Rossetti, L. (2004). Hypothalamic responses to longchain fatty acids are nutritionally regulated. J. Biol. Chem. 279, 31139-31148. doi: 10.1074/jbc.M400458200

Morrison, C. D., Xi, X., White, C. L., Ye, J., and Martin, R. J. (2016). Amino acids inhibit Agrp gene expression via an mTOR-dependent mechanism. Am. J. Physiol. Endocrinol. Metab. 293, E165-E171. doi: 10.1152/ajpendo.00675.2006

Morton, G. J., Cummings, D. E., Baskin, D. G., Barsh, G. S., and Schwartz, M. W. (2006). Central nervous system control of food intake and body weight. Nature 443, 289-295. doi: 10.1038/nature05026

Morton, G. J., Meek, T. H., and Schwartz, M. W. (2014). Neurobiology of food intake in health and disease. Nat. Rev. Neurosci. 15, 367-378. doi: $10.1038 / \mathrm{nrn} 3745$

Mourente, G., and Tocher, D. R. (1992). Lipid class and fatty acid composition of brain lipids from Atlantic herring (Clupea harengus) at different stages of development. Mar. Biol. 112, 553-558. doi: 10.1007/BF00346172

Murashita, K., Kurokawa, T., Ebbesson, L. O. E., Stefansson, S. O., and Ronnestad, I. (2009). Characterization, tissue distribution, and regulation of agouti-related protein (AgRP), cocaine- and amphetamine-regulated transcript (CART) and neuropeptide Y (NPY) in Atlantic salmon (Salmo salar). Gen. Comp. Endocrinol. 162, 160-171. doi: 10.1016/j.ygcen.2009. 03.015

Murashita, K., Uji, S., Yamamoto, T., Rønnestad, I., and Kurokawa, T. (2008). Production of recombinant leptin and its effects on food intake in rainbow trout (Oncorhynchus mykiss). Comp. Biochem. Physiol. B. 150, 377-384. doi: 10.1016/j.cbpb.2008.04.007

Murovets, V. O., Bachmanov, A. A., and Zolotarev, V. A. (2015). Impaired glucose metabolism in mice lacking the Tas $1 r 3$ taste receptor gene. PLoS ONE 10:0130997. doi: 10.1371/journal.pone.0130997

Narnaware, Y. k., and Peter, R. E. (2002). Influence of diet composition on food intake and neuropeptide Y (NPY) gene expression in goldfish brain. Reg. Peptides 103, 75-83. doi: 10.1016/S0167-0115(01)00342-1
Navarro, I., and Gutiérrez, J. (1995). "Fasting and starvation," in Biochemistry and Molecular Biology of Fishes, eds P. W. Hochachka and T. P. Mommsen (New York, NY: Elsevier), 394-434.

Nolan, C. J., Madiraju, M. S., Delghingaro-Augusto, V., Peyot, M. L., and Prentki, M. (2006). Fatty acid signaling in the beta-cell and insulin secretion. Diabetes 55, S16-S23. doi: $10.2337 / \mathrm{db} 06-\mathrm{S} 003$

Obici, S., Feng, Z., Morgan, K., Stein, D., Karkanias, G., and Rossetti, L. (2002). Central administration of oleic acid inhibits glucose production and food intake. Diabetes 51, 271-275. doi: 10.2337/diabetes.51.2.271

Ogunnowo-Bada, E., Heeley, N., Brochard, L., and Evans, M. L. (2014). Brain glucose sensing, glucokinase and nural control of metabolism and islet function. Diab. Obes. Metab. 16, 26-32. doi: 10.1111/dom.12334

Oh, Y. T., Kim, J., Kang, I., and Youn, J. H. (2014). Regulation of hypothalamic-pituitary-adrenal axis by circulating free fatty acids in male wistar rats: role of individual free fatty acids. Endocrinology 155, 923-931. doi: 10.1210/en.2013-1700

Oh, Y. T., Oh, H. H., Nguyen, A. K., Choi, C. S., and Youn, J. H. (2016). Circulating free fatty acids inhibit food intake in an oleate-specific manner in rats. Physiol. Behav. 167, 194-201. doi: 10.1016/j.physbeh.2016.09.015

Oh, Y. T., Oh, K. S., Kang, I., and Youn, J. H. (2012). A fall in plasma free fatty acid (FFA) level activates the hypothalamic-pituitary-adrenal axis independent of plasma glucose: evidence for brain sensing of circulating FFA. Endocrinology 153, 3587-3592. doi: 10.1210/en.2012-1330

Ooyama, Y., Kojima, K., Aoyama, T., and Takeuchi, H. (2009). Decrease of food intake in rats after ingestion of medium-chain triacylglycerol. J. Nutr. Sci. Vitaminol. 55, 423-427. doi: 10.3177/jnsv.55.423

Osundiji, M. A., Lam, D. D., Shaw, J., Yueh, C. Y., Markkula, S. P., Hurst, P., et al. (2012). Brain glucose sensors play a significant role in the regulation of pancreatic glucose-stimulated insulin secretion. Diabetes 61, 321-328. doi: $10.2337 / \mathrm{db} 11-1050$

Otero-Rodiño, C., Librán-Pérez, M., Velasco, C., López-Patiño, M. A., Míguez, J. M., and Soengas, J. L. (2015). Evidence for the presence of glucosensor mechanisms not dependent on glucokinase in hypothalamus and hindbrain of rainbow trout (Oncorhynchus mykiss). PLoS ONE 10:e0128603. doi: 10.1371/journal.pone.0128603

Otero-Rodiño, C., Librán-Pérez, M., Velasco, C., Álvarez-Otero, R., LópezPatiño, M. A., Míguez, J. M., et al. (2016b). Glucosensing in liver and Brockmann bodies of rainbow trout through glucokinase-independent mechanisms. Comp. Biochem. Physiol. B. 199, 29-42. doi: 10.1016/j.cbpb.2015. 09.008

Otero-Rodiño, C., Velasco, C., Álvarez-Otero, R., López-Patiño, M. A., Míguez, J. M., and Soengas, J. L. (2016a). In vitro evidence supports the presence of glucokinase-independent glucosensing mechanisms in hypothalamus and hindbrain of rainbow trout. J. Exp. Biol. 219, 1750-1759. doi: $10.1242 /$ jeb. 137737

Otero-Rodiño, C., Velasco, C., Álvarez-Otero, R., López-Patiño, M. A., Míguez, J. M., and Soengas, J. L. (2016c). In vitro evidence in rainbow trout supporting glucosensing mediated by sweet taste receptor, LXR, and mitochondrial activity in Brockmann bodies, and sweet taste receptor in liver. Comp. Biochem. Physiol. B. 200, 6-16. doi: 10.1016/j.cbpb.2016.04.010

Panserat, S., Capilla, E., Gutierrez, J., Frappart, P. O., Vachot, C., PlagnesJuan, E., et al. (2001). Glucokinase is highly induced and glucose-6phosphatase poorly repressed in liver of rainbow trout (Oncorhynchus mykiss) by a single meal with glucose. Comp. Biochem. Physiol. B 128, 275-283. doi: 10.1016/S1096-4959(00)00322-5

Panserat, S., Medale, F., Blin, C., Breque, J., Vachot, C., Plagnes-Juan, E., et al. (2000). Hepatic glucokinase is induced by dietary carbohydrates in rainbow trout, gilthead seabream, and common carp. Am. J. Physiol. Regul. Integr. Comp. Physiol. 278, 1164-1170.

Panserat, S., Perrin, A., and Kaushik, S. (2002a). High dietary lipid induce liver glucose-6 phosphatase expression in rainbow trout (Oncorhynchus mykiss). J. Nutr. 132, 137-141.

Panserat, S., Plagnes-Juan, E., and Kaushik, S. (2002b). Gluconeogenic enzyme gene expression is decreased by dietary carbohydrates in common carp (Cyprinus carpio) and gilthead seabream (Sparus aurata). Biochim. Biophys. Acta 1579, 35-42. doi: 10.1016/S0167-4781(02)00501-8

Peddu, S. C., Breves, J. P., Kaiya, H., Grau, E. G., and Riley, L. G. Jr. (2009). Pre- and postprandial effects on ghrelin signaling in the brain and on the 
GH/IGF-I axis in the Mozambique tilapia (Oreochromis mossambicus). Gen. Comp. Endocrinol. 161, 412-418. doi: 10.1016/j.ygcen.2009.02.008

Penney, C. C., and Volkoff, H. (2014). Peripheral injections of cholecystokinin, apelin, ghrelin and orexin in cavefish (Astyanax fasciatus mexicanus): effects on feeding and on the brain expression levels of tyrosine hydroxylase, mechanistic target of rapamycin and appetite-related hormones. Gen. Comp. Endocrinol. 196, 34-40. doi: 10.1016/j.ygcen.2013.11.015

Peragón, J., Barroso, J. B., García-Salguero, L., de la Higuera, M., and Lupiáñez, J. A. (2000). Dietary alterations in protein, carbohydrates and fat increase liver protein-turnover rate and decrease overall growth rate in the rainbow trout (Oncorhynchus mykiss). Comp. Biochem. Physiol. 209, 97-104.

Peterson, B. C., Waldbieser, G. C., Riley, L. G. Jr., Upton, K. R., Kobayashi, Y., and Small, B. C. (2012). Pre- and postprandial changes in orexigenic and anorexigenic factors in channel catfish (Ictalurus punctatus). Gen. Comp. Endocrinol. 176, 231-239. doi: 10.1016/j.ygcen.2012.01.022

Pfannkuche, H., and Gäbel, G. (2009). Glucose, epithelium, and enteric nervous system: dialogue in the dark. J. Anim. Physiol. Anim. Nutr. (Berl) 93, 277-286. doi: 10.1111/j.1439-0396.2008.00847.x

Picard, A., Rouch, C., Kassis, N., Moullé, V. S., Croizier, S., Denis, R. G., et al. (2013). Hippocampal lipoprotein lipase regulates energy balance in rodents. Mol. Metab. 3, 167-176. doi: 10.1016/j.molmet.2013.11.002

Picha, M. E., Strom, C. N., Riley, L. G., Walker, A. A., Won, E. T., Johnstone, W. M., et al. (2009). Plasma ghrelin and growth hormone regulation in response to metabolic state in hybrid striped bass: effects of feeding, ghrelin and insulin-like growth factor-I on in vivo and in vitro GH secretion. Gen. Comp. Endocrinol. 161, 365-372. doi: 10.1016/j.ygcen.2009.01.026

Plagnes-Juan, E., Lansard, M., Seiliez, I., Médale, F., Corraze, G., Kaushik, S., et al. (2008). Insulin regulates the expression of several metabolism-related genes in the liver and primary hepatocytes of rainbow trout (Oncorhynchus mykiss). J. Exp. Biol. 211, 2510-2518. doi: 10.1242/jeb.018374

Pocai, A., Obici, S., Schwartz, G. J., and Rossetti, L. (2005). A brainliver circuit regulates glucose homeostasis. Cell. Metab. 1, 53-61. doi: 10.1016/j.cmet.2004.11.001

Polakof, S., Medale, F., Larroquet, L., Vachot, C., Corraze, G., and Panserat, S. (2011f). Regulation of de novo hepatic lipogenesis by insulin infusion in rainbow trout fed a high-carbohydrate diet. J. Anim. Sci. 89, 3079-3088. doi: $10.2527 /$ jas.2010-3733

Polakof, S., Médale, F., Skiba-Cassy, S., Corraze, G., and Panserat, S. (2010b). Molecular regulation of lipid metabolism in liver and muscle of rainbow trout subjected to acute and chronic insulin treatments. Domestic Anim. Endocrinol. 39, 26-33. doi: 10.1016/j.domaniend.2010.01.003

Polakof, S., Míguez, J. M., Moon, T. W., and Soengas, J. L. (2007a). Evidence for the presence of a glucosensor in hypothalamus, hindbrain, and Brockmann bodies of rainbow trout. Am. J. Physiol. Regul. Integr. Comp. Physiol. 292, R1657-R1666. doi: 10.1152/ajpregu.00525.2006

Polakof, S., Míguez, J. M., and Soengas, J. L. (2007b). In vitro evidences for glucosensing capacity and mechanisms in hypothalamus, hindbrain, and Brockmann bodies of rainbow trout. Am. J. Physiol. Regul. Integr. Comp. Physiol. 293, R1410-R1420. doi: 10.1152/ajpregu.00283.2007

Polakof, S., Míguez, J. M., and Soengas, J. L. (2008a). Changes in food intake and glucosensing function of hypothalamus and hindbrain in rainbow trout subjected to hyperglycemic or hypoglycemic conditions. J. Comp. Physiol. A. 194, 829-839. doi: 10.1007/s00359-008-0354-y

Polakof, S., Míguez, J. M., and Soengas, J. L. (2008b). Dietary carbohydrates induce changes in glucosensing capacity and food intake in rainbow trout. Am. J. Physiol. Regul. Integr. Comp. Physiol. 295, R478-R489. doi: 10.1152/ajpregu.00176.2008

Polakof, S., Míguez, J. M., and Soengas, J. L. (2011a). Cholecystokinin impact on rainbow trout glucose homeostasis: possible involvement of central glucosensors. Reg. Peptides 172, 23-29. doi: 10.1016/j.regpep.2011. 08.002

Polakof, S., Míguez, J. M., and Soengas, J. L. (2011b). Evidence for a gutbrain axis used by glucagon-like peptide-1 to elicit hyperglycaemia in fish. J. Neuroendocrinol. 23, 508-518. doi: 10.1111/j.1365-2826.2011.02137.x

Polakof, S., Míguez, J. M., and Soengas, J. L. (2011c). Ghrelin effects on central glucosensing ad energy homeostasis-related peptides in rainbow trout. Domestic Anim. Endocrinol. 41, 126-136. doi: 10.1016/j.domaniend.2011. 05.006
Polakof, S., Mommsen, T. P., and Soengas, J. L. (2011d). Glucosensing and glucose homeostasis: from fish to mammals. Comp. Biochem. Physiol. B. 160, 123-149. doi: 10.1016/j.cbpb.2011.07.006

Polakof, S., Panserat, S., Craig, P. M., Martyres, D. J., Plagnes-Juan, E., Savari, S., et al. (2011e). The metabolic consequences of hepatic AMP-kinase phosphorylation in rainbow trout. PLOS ONE 6:e20228. doi: 10.1371/journal.pone.0020228

Polakof, S., Panserat, S., Plagnes-Juan, E., and Soengas, J. L. (2008c). Altered dietary carbohydrates significantly affect gene expression of the major glucosensing components in Brockmannn bodies and hypothalamus of rainbow trout. Am. J. Physiol. Regul. Integr. Comp. Physiol. 295, R1077-R1088. doi: 10.1152/ajpregu.90476.2008

Polakof, S., Panserat, S., Soengas, J. L., and Moon, T. W. (2012a). Glucose metabolism in fish: a review. J. Comp. Physiol. B. 182, 1015-1045. doi: 10.1007/ s00360-012-0658-7

Polakof, S., Rodríguez-Alonso, M., and Soengas, J. L. (2009). Immunohistochemical localization of glucokinase in rainbow trout brain. Comp. Biochem. Physiol. A. 153, 352-358. doi: 10.1016/j.cbpa.2009. 03.015

Polakof, S., Alvarez, R., and Soengas, J. L. (2010a). Gut glucose metabolism in rainbow trout: implications in glucose homeostasis and glucosensing capacity. Am. J. Physiol. Regul. Integr. Comp. Physiol. 299, R19-R32. doi: 10.1152/ajpregu.00005.2010

Polakof, S., Skiba-Cassy, S., Kaushik, S., Seiliez, I., Soengas, J. L., and Panserat, S. (2012b). Glucose and lipid metabolism in the pancreas of rainbow trout is regulated at the molecular level by nutritional status and carbohydrate intake. J. Comp. Physiol. B. 182, 507-516. doi: 10.1007/s00360-011-0636-5

Polakof, S., and Soengas, J. L. (2008). Involvement of lactate in glucose metabolism and glucosensing function in selected tissues of rainbow trout. J. Exp. Biol. 211, 1075-1086. doi: 10.1242/jeb.014050

Polakof, S., and Soengas, J. L. (2013). Evidence of sugar sensitive genes in the gut of a carnivorous fish species. Comp. Biochem. Physiol. B. 166, 58-64. doi: $10.1016 /$ j.cbpb.2013.07.003

Rasmussen, R. S., Ostenfeld, T. H., Rønsholdt, B., and McLean, E. (2000). Manipulation of end-product quality of rainbow trout with finishing diets. Aquacult. Nutr. 6, 17-23. doi: 10.1046/j.1365-2095.2000.00119.x

Ren, X., Zhou, L., Terwiliger, R., Newton, S. S., and de Araujo, I. E. (2009). Sweet taste signaling functions as a hypothalamic glucose sensor. Front. Integr. Neurosci. 3:12. doi: 10.3389/neuro.07.012.2009

Rogers, R. C., Ritter, S., and Hermann, G. E. (2016). Hindbrain cytoglucopeniainduced increases in systemic blood glucose levels by 2-deoxyglucose depend on intact astrocytes adn adenosine release. Am. J. Physiol. Regul. Integr. Comp. Physiol. 310, R1102-R1108. doi: 10.1152/ajpregu. 00493.2015

Roh, E., Song do, K., and Kim, M. (2016). Emerging role of the brain in the homeostatic regulation of energy and glucose metabolism. Exp. Mol. Med. 48, e216. doi: 10.1038/emm.2016.4

Ronner, P. (1991). 2-Deoxyglucose stimulates the release of insulin and somatostatin from the perfused catfish pancreas. Gen. Comp. Endocrinol. 81, 276-283. doi: 10.1016/0016-6480(91)90012-U

Ronner, P., and Scarpa, A. (1987). Secretagogues for pancreatic hormone release in the channel catfish. Gen. Comp. Endocrinol. 65, 354-362. doi: 10.1016/0016-6480(87)90120-1

Ross, R. A., Rossetti, L., Lam, T. K., and Schwartz, G. J. (2010). Differential effects of hypothalamic long-chain fatty acid infusions on suppression of hepatic glucose production. Am. J. Physiol. Endocrinol. Metab. 299, E633-E639. doi: 10.1152/ajpendo.00190.2010

Rubio, V. C., Sánchez-Vázquez, F. J., and Madrid, J. A. (2008). Role of cholecystokinin and its antagonist proglumide on macronutrient selection in European sea bass Dicentrarchus labrax, L. Physiol. Behav. 93, 862-869. doi: 10.1016/j.physbeh.2007.12.001

Ruderman, N. B., Xu, X. J., Nelson, L., Cacicedo, J. M., Saha, A. K., Lan, F., et al. (2010). AMPK and SIRT1: a long-standing partnership? Am. J. Physiol. Endocrinol. Metab. 298, E751-E760. doi: 10.1152/ajpendo.00745.2009

Ruibal, C., Soengas, J. L., and Aldegunde, M. (2002). Brain serotonin and the control of food intake in rainbow trout (Oncorhynchus mykiss): effects of changes in plasma glucose levels. J. Comp. Physiol. A. 188, 479-484. doi: $10.1007 / \mathrm{s} 00359-002-0320-\mathrm{z}$ 
Rutter, G. A., Pullen, T. J., Hodson, D. J., and Martinez-Sanchez, A. (2015). Pancreatic $\beta$-cell identity, glucose sensing and the control of insulin secretion. Biochem. J. 466, 203-218. doi: 10.1042/BJ20141384

Sánchez-Gurmaches, J., Cruz-Garcia, L., Gutiérrez, J., and Navarro, I. (2010). Endocrine control of oleic acid and glucose metabolism in rainbow trout (Oncorhynchus mykiss) muscle cells in culture. Am. J. Physiol. Regul. Integr. Comp. Physiol. 299, R562-R572. doi: 10.1152/ajpregu.00696.2009

Sánchez-Muros, M. J., García-Rejón, L., García-Salguero, L., de la Higuera, M., and Lupiáñez, J. A. (1998). Long-term nutritional effects on the pimary liver and kidney metabolism in rainbow trout. Adaptative response to starvation and high-protein, carbohydrate-free diet to glutamate dehydrogenase and alanine aminotransferase kinetics. Int. J. Biochem. 30, 55-63.

Sanders, N. M., Dunn-Meynell, A. A., and Levin, B. E. (2004). Third ventricular alloxan reversibly impairs glucose conterregulatory responses. Diabetes 53, 1230-1236. doi: 10.2337/diabetes.53.5.1230

Saravanan, S., Geurden, I., Figueiredo-Silva, A. C., Kaushik, S., Haidar, M. N., Verreth, J. A. J., et al. (2012). Control of voluntary feed intake in fish: a role for dietary oxygen demand in Nile tilapia (Oreochromis niloticus) fed diets with different macronutrient profiles. Br. J. Nutr. 108, 1519-1529. doi: $10.1017 /$ S0007114511006842

Saravanan, S., Geurden, I., Figueiredo-Silva, A. C., Kaushik, S., Verreth, J. A. J., and Schrama, J. W. (2013). Voluntary feed intake in rainbow trout is regulated by diet-induced diferences in oxygen use. J. Nutr. 143, 781-787. doi: $10.3945 /$ jn.112.173062

Sargent, J. R., Tocher, D. R., and Bell, J. G. (2002). "The lipids," in Fish Nutrition, eds J. E. Halver and R. W. Hardy (San Diego, CA: Academic Press), 182-258.

Schroeter, J. C., Fenn, C. M., and Small, B. C. (2015). Elucidating the roles of gut neuropeptides on channel catfish feed intake, glycemia, and hypothalamic NPY and POMC expression. Comp. Biochem. Physiol. A. 188, 168-174. doi: 10.1016/j.cbpa.2015.06.031

Schwartz, M. W., Woods, S. C., Porte, D. Jr., Seeley, R. J., and Baskin, D. G. (2000). Central nervous system control of food intake. Nature 404, 661-671.

Schwinkendorf, D. R., Tsatsos, N. G., Gosnell, B. A., and Mashek, D. G. (2011). Effects of central administration of distinct fatty acids on hypothalamic neuropeptide expression and energy metabolism. Int. J. Obes. 35, 336-344. doi: 10.1038/ijo.2010.159

Seiliez, I., Gabillard, J. C., Skiba-Cassy, S., Garcia-Serrana, D., Gutiérrez, J., Kaushik, S., et al. (2008). An in vivo and in vitro assessment of TOR signaling cascade in rainbow trout (Oncorhynchus mykiss). Am. J. Physiol. Regul. Integr. Comp. Physiol. 295, R329-R335. doi: 10.1152/ajpregu.001 46.2008

Seiliez, I., Médale, F., Aguirre, P., Larquier, M., Lanneretonne, L., Alami-Durante, H., et al. (2013). Postprandial regulation of growth- and metabolism-related factors in zebrafish. Zebrafish 10, 237-248. doi: 10.1089/zeb.2012.0835

Seth, H., and Axelsson, M. (2010). Sympathetic, parasympathetic and enteric regulation of the gastrointestinal vasculature in rainbow trout (Oncorhynchus mykiss) under normal and postprandial conditions. J. Exp. Biol. 213, 3118-3126. doi: $10.1242 /$ jeb. 043612

Shearer, K. D., Silverstein, J., and Plisetskaya, E. M. (1997). Role of adiposity in food intake control of juvenile chinook salmon (Oncorhynchus tshawytscha). Comp. Biochem. Physiol. A. 118, 1209-1215. doi: 10.1016/S0300-9629(97)86801-6

Sheridan, M. A. (1994). Regulation of lipid metabolism in poikilothermic vertebrates. Comp. Biochem. Physiol. B. 107, 495-508. doi: 10.1016/03050491(94)90176-7

Silverstein, J. T., Bondareva, V. M., Leonard, J. B., and Plisetskaya, E. M. (2001). Neuropeptide regulation of feeding in catfish, Ictalurus punctatus: a role for glucagon-like peptide-1 (GLP-1)? Comp. Biochem. Physiol. B. 129, 623-631. doi: 10.1016/S1096-4959(01)00357-8

Silverstein, J. T., and Plisetskaya, E. M. (2000). The effects of NPY and insulin on food intake regulation in fish. Am. Zool. 40, 296-308. doi: 10.1093/icb/40.2.296

Silverstein, J. T., Shearer, K. D., Dickhoff, W. W., and Plisetskaya, E. M. (1999). Regulation of nutrient intake and energy balance in salmon. Aquaculture 177, 161-169. doi: 10.1016/S0044-8486(99)00076-9

Skiba-Cassy, S., Lansard, M., Panserat, S., and Médale, F. (2009). Rainbow trout genetically selected fo greater muscle fat content display increased activation of liver TOR signaling and lipogenic gene expression. Am. J. Physiol. Regul. Integr. Comp. Physiol. 297, R1421-R1429. doi: 10.1152/ajpregu.003 12.2009
Soengas, J. L. (2014). Contribution of glucose- and fatty acid sensing systems to the regulation of food intake in fish. A review. Gen. Comp. Endocrinol. 205, 36-48. doi: 10.1016/j.ygcen.2014.01.015

Soengas, J. L., and Aldegunde, M. (2004). Brain glucose and insulin: effects on food intake and brain biogenic amines of rainbow trout. J. Comp. Physiol. A. 190, 641-649. doi: 10.1007/s00359-004-0524-5

Soengas, J. L., and Moon, T. W. (1998). Transport and metabolism of glucose in isolated enterocytes of the black bullhead Ictalurus melas: effects of diet and hormones. J. Exp. Biol. 201, 3263-3273.

Soengas, J. L., Polakof, S., Chen, X., Sangiao-Alvarellos, S., and Moon, T. W. (2006). Glucokinase and hexokinase expression and activities in rainbow trout tissues: changes with food deprivation and refeeding. Am. J. Physiol. Regul. Integr. Comp. Physiol. 291, R810-R821. doi: 10.1152/ajpregu.00115.2006

Song, Y., Golling, G., Thacker, T. L., and Cone, R. D. (2003). Agouti-related protein (AGRP) is conserved and regulated by metabolic state in the zebrafish, Danio rerio. Endocrine 22, 257-265. doi: 10.1385/ENDO:22:3:257

Suárez, M. D., Sanz, A., Bazoco, J., and García-Gallego, M. (2002). Metabolic effects of changes in the dietary protein:carbohydrate ratio in eel (Anguilla anguilla) and trout (Oncorhynchus mykiss). Aquacult. Int. 10, 143-156. doi: 10.1023/A:1021371104839

Subhedar, N., Varsagade, V. G., Singru, P. S., Thim, L., and Clausen, J. T. (2011). Cocaine- and amphetamine-regulated transcript peptide (CART) in the telencephalon of the catfish, Clarias gariepinus: distribution and response to fasting, 2-deoxy-D-glucose, glucose, insulin, and leptin treatments. J. Comp. Neurol. 519, 1281-1300. doi: 10.1002/cne.22569

Tang, Z., Sun, C., Yan, A., Wu, S., Qin, C., Zhang, Y., et al. (2013). Genes involved in fatty acid metabolism: molecular characterization and hypothalamic mRNA response to energy status and neuropeptide $\mathrm{Y}$ treatment in the orangespotted grouper Epinephelus coioides. Mol. Cell Endocrinol. 376, 114-124. doi: 10.1016/j.mce.2013.06.020

Thorens, B. (2011). Brain glucose sensing and neural regulation of insulin and glucagon secretion. Diabet. Obes. Metab. 1, 82-88. doi: 10.1111/j.14631326.2011.01453.x

Thorens, B. (2012). "Sensing of glucose in the brain," in Appetite Control, ed H. G. Joost (Berlin: Springer-Verlag), 277-293.

Tian, J., He, G., Mai, K., and Liu, C. (2015). Effects of postprandial starvation on mRNA expression of endocrine-, amino acid and peptide transporter-, and metabolic enzyme-related genes in zebrafish (Danio rerio). Fish Physiol. Biochem. 41, 773-787. doi: 10.1007/s10695-015-0045-x

Tinoco, A. B., Näslund, J., Delgado, M. J., de Pedro, N., Johnsson, J. I., and Jönsson, E. (2014). Ghrelin increases food intake, swimming activity and growth in juvenile brown trout (Salmo trutta). Physiol. Behav. 124, 15-22. doi: 10.1016/j.physbeh.2013.10.034

Tocher, D. R. (2003). Metabolism and functions of lipids and fatty acids in teleost fish. Rev. Fish. Sci. 11, 107-184. doi: 10.1080/713610925

Tocher, D. R., Mourente, G., and Sargent, J. R. (1992). Metabolism of $\left[1-{ }^{14} \mathrm{C}\right]$ Docosahexaenoate (22:6n-3), $\left[1-{ }^{14} \mathrm{C}\right]$ Eicosapentaenoate (20:5n-3) and $\left[1-{ }^{14} \mathrm{C}\right]$ Linolenate $(18: 3 \mathrm{n}-3)$ in brain cells from juvenile turbot Scophthalmus maximus. Lipids 27, 494-499. doi: 10.1007/BF02536129

Torstensen, B. E., Nanton, D. A., Olsvik, P. A., Sundvold, H., and Stubhaug,I. (2009). Gene expression of fatty acid-binding proteins, fatty acid transport proteins (cd36 and FATP) and $\beta$-oxidation-related genes in Atlantic salmon (Salmo salar L.) fed fish oil or vegetable oil. Aquaculture Nutr. 15, 440-451. doi: 10.1111/j.1365-2095.2008.00609.x

Tranulis, M. A., Dregni, O., Christophersen, B., Krogdahl, A., and Borrebaek, B. (1996). A glucokinase-like-enzyme in the liver of Atlantic salmon (Salmo salar). Comp. Biochem. Physiol. A. 114, 35-39. doi: 10.1016/0305-0491(95)02119-1

Treesukosol, Y., Smith, K. R., and Spector, A. C. (2011). The functional role of the T1R family of receptors in sweet taste and feeding. Physiol. Behav. 105, 14-26. doi: 10.1016/j.physbeh.2011.02.030

Trushenski, J. T. (2009). Saturated lipid sources in feeds for sunshine bass: alterations in production performance and tissue fatty acid composition. North Am. J. Aquacult. 71, 363-373. doi: 10.1577/A09-001.1

Tu, Y., Xie, S., Han, D., Yang, Y., Jin, J., and Zhu, X. (2015). Dietary arginine requirement for gibel carp (Carassius auratus gibelio var. CAS III) reduces with fish size from $50 \mathrm{~g}$ to $150 \mathrm{~g}$ associated with modulation of genes involved in TOR signaling pathway. Aquaculture 449, 37-47. doi: 10.1016/j.aquaculture.2015.02.031 
Vaulont, S., Vasseur-Cognet, M., and Kahn, A. (2000). Glucose regulation of gene transcription. J. Biol. Chem. 275, 31555-31558. doi: 10.1074/jbc.R000016200

Velasco, C., Librán-Pérez, M., Otero-Rodiño, C., López-Patiño, M. A., Míguez, J. M., Cerdá-Reverter, J. M., et al. (2016a). Ghrelin modulates hypothalamic fatty acid-sensing and control of food intake in rainbow trout. J. Endocrinol. 228, 25-37. doi: 10.1530/JOE-15-0391

Velasco, C., Librán-Pérez, M., Otero-Rodiño, C., López-Patiño, M. A., Míguez, J. M., and Soengas, J. L. (2016b). Ceramides are involved in regulation of food intake in rainbow trout (Oncorhynchus mykiss). Am. J. Physiol. Regul. Integr. Comp. Physiol. 311, R658-R668. doi: 10.1152/ajpregu.00201.2016

Velasco, C., Librán-Pérez, M., Otero-Rodiño, C., López-Patiño, M. A., Míguez, J. M., and Soengas, J. L. (2016c). Intracerebroventricular ghrelin treatment affects lipid metabolism in liver of rainbow trout (Oncorhynchus mykiss). Gen. Comp. Endocrinol. 228, 33-39. doi: 10.1016/j.ygcen.2016.01.016

Velásquez, D. A., Martinez, G., Romero, A., Vázquez, M. J., Boit, K. D., DopesoReyes, I. G., et al. (2011). The central sirtuin 1/p53 pathway is essential for the orexigenic action of ghrelin. Diabetes 60, 1177-1185. doi: 10.2337/db10-0802

Vivas, Y., Azpeleta, C., Feliciano, A., Velarde, E., Isorna, E., Delgado, M. J., et al. (2011). Time-dependent effects of leptin on food intake and locomotor activity in goldfish. Peptides 32, 989-995. doi: 10.1016/j.peptides.2011.01.028

Volkoff, H. (2006). The role of neuropeptide Y, orexins, cocaine and amphetamine-related transcript, cholecystokinin, amylin and leptin in the regulation of feeding in fish. Comp. Biochem. Physiol. A. 144, 325-331. doi: $10.1016 /$ j.cbpa.2005.10.026

Volkoff, H., Canosa, L. F., Unniappan, S., Cerdá-Reverter, J. M., Bernier, N. J., Kelly, S. P., et al. (2005). Neuropeptides and the control of food intake in fish. Gen. Comp. Endocrinol. 142, 3-19. doi: 10.1016/j.ygcen.2004.11.001

Volkoff, H., Eykelbosh, A. J., and Peter, R. E. (2003). Role of leptin in the control of feeding of goldfish Carassius auratus: interactions with cholecystokinin, neuropeptide $\mathrm{Y}$ and orexin A, and modulation by fasting. Brain Res. 972, 90-109. doi: 10.1016/S0006-8993(03)02507-1

Volkoff, H., Hoskins, L. J., and Tuziak, S. M. (2009). Influence of intrinsic signals and environmental cue on the endocrine control of feeding in fish: potential application in aquaculture. Gen. Comp. Endocrinol. 167, 352-359. doi: 10.1016/j.ygcen.2009.09.001

Volkoff, H., and Peter, R. E. (2001). Characterization of two forms of cocaine- and amphetamine-regulated transcript (CART) peptide precursors in goldfish: molecular cloning and distribution, modulation of expression by nutritional status, and interactions with leptin. Endocrinology 142, 5076-5088. doi: 10.1210/endo.142.12.8519

Wacyk, J., Powell, M., Rodnick, K. J., Overturf, K., Hill, R. A., and Hardy, R. (2012). Dietary protein source significantly alters growth performance, plasma variables and hepatic gene expression in rainbow trout (Oncorhynchus mykiss) fed amino acid balanced diets. Aquaculture 356-357, 223-234. doi: 10.1016/j.aquaculture.2012.05.013
Wang, W. G., Chen, X., Jiang, H., and Jiang, Z. Y. (2008). Effects of ghrelin on glucose-sensing and gastric distension sensitive neurons in rat dorsal vagal complex. Regul. Peptides 146, 169-175. doi: 10.1016/j.regpep.2007. 09.007

Wauson, E. M., Lorente-Rodríguez, A., and Cobb, M. H. (2013). Minireview: nutrient sensing by $\mathrm{G}$ protein-couples receptors. Mol. Endocrinol. 27, 1188-1197. doi: 10.1210/me.2013-1100

White, S. L., Volkoff, H., and Devlin, R. H. (2016). Regulation of feeding behavior and food intake by appetite-regulating peptides in wild-type and growth hormone-transgenic coho salmon. Horm. Behav. 84, 18-28. doi: 10.1016/j.yhbeh.2016.04.005

Williams, I., Williams, K. C., Smith, D. M., and Jones, M. (2006). Polka-dot grouper, Cromileptes altivelis, can utilize dietary fat efficiently. Aquacult. Nutr. 12, 379-387. doi: 10.1111/j.1365-2095.2006.00437.x

Won, E. T., Baltzegar, D. A., Picha, M. E., and Borski, R. J. (2012). Cloning and characterization of leptin in a Perciform fish, the striped bass (Morone saxatilis): control of feeding and regulation by nutritional state. Gen. Comp. Endocrinol. 178, 98-107. doi: 10.1016/j.ygcen.2012.04.019

Xu, D., He, G., Mai, K., Xu, W., and Song, F. (2016). Postprandial nutrientsensing and metabolic responses after partial dietary replacement by soyabean meal in turbot (Scophthalmus maximus L.). Br. J. Nutr. 115, 379-388. doi: $10.1017 /$ S0007114515004535

Zheng, H., and Berthoud, H. R. (2008). Neural systems controlling the drive to eat: mind versus metabolism. Physiology 23, 75-83. doi: 10.1152/physiol.00047.2007

Zhong, C., Song, Y., Wang, Y., Zhang, T., Duan, M., Li, Y., et al. (2013). Increased food intake in growth hormone-transgenic common carp (Cyprinus carpio L.) may be mediated by upregulating Agouti-related protein (AgRP). Gen. Comp. Endocrinol. 192, 81-88. doi: 10.1016/j.ygcen.2013.03.024

Zhou, Y., Liang, X.-F., Yuan, X., Jie, L., He, Y., Fang, L., et al. (2013). Neuropeptide $\mathrm{Y}$ stimulates food intake and regulates metabolism in grass carp, Ctenopharyngodon idellus. Aquaculture 380-383, 52-61. doi: 10.1016/j.aquaculture.2012.11.033

Conflict of Interest Statement: The authors declare that the research was conducted in the absence of any commercial or financial relationships that could be construed as a potential conflict of interest.

Copyright (c) 2017 Conde-Sieira and Soengas. This is an open-access article distributed under the terms of the Creative Commons Attribution License (CC BY). The use, distribution or reproduction in other forums is permitted, provided the original author(s) or licensor are credited and that the original publication in this journal is cited, in accordance with accepted academic practice. No use, distribution or reproduction is permitted which does not comply with these terms. 